\title{
TESTATE AMOEBAE AS BIO-INDICATORS OF CONTAMINATION BY TRACE ELEMENTS IN THE RESERVOIR OF SALTO GRANDE AMERICANA-SP, BRAZIL
}

\author{
Maria laura Misailidis ${ }^{*}$, Nicolás Misailidis Strikis ${ }^{2}$, Rubens Cesar Figueira ${ }^{3}$, Renato Campello Cordeiro ${ }^{2}$, \\ Pedro Carlos Strikis ${ }^{4}$, Leonardo Antonio Pregnolato ${ }^{1}$ and Wânia Duleba ${ }^{1}$
}

1 Escola de Artes, Ciências e Humanidades (EACH) Universidade de São Paulo. Rua Arlindo Béttio, 1000 - Jardim Keralux, São Paulo - SP, 03828-000, Brazil.mlmisailidis@gmail.com, leopregnolato@outlook.com, wduleba@gmail.com

2 Departamento de Geoquímica, Universidade Federal Fluminense, Rua Outeiro de São João Batista s/n, Campus do Valonguinho Centro Niterói - RJ 24020-141, Brazil. strikis@gmail.com, rcampellocordeiro@gmail.com

3 Instituto Oceanográfico Universidade de São Paulo. Praça do Oceanográico, 191, São Paulo - SP, 05508-120, Brazil. rfigueira@usp.br

4 Instituto de Geociências Universidade de São Paulo. Rua do Lago, 562, Butantã, São Paulo - SP, 05508-080, Brazil. pctrikis@usp.br

*Corresponding author, mlmisailidis@gmail.com

\section{SCREENED BY iThenticate}

Received on 9 Novemvber 2017

Received in revised form on 22 January 2018

Accepted on 26 January 2018

Editor: MariaV irginia Alves Martins, Universidade do Estado do Rio de Janeiro, Brazil

\section{Abstract}

This work aims to evaluate the degree of sediment contamination and the response of Testate amoebae populations through a sediment core taken from the Salto Grande Reservoir (RSG), situated in Americana, in São Paulo State (SP), Brazil. It is based on the analysis of the trace elements geochemistry (by ICP-OES) and Testate amoebae data (by stereomicroscopic morphometric analysis). The indices of homogeneity and richness (Simpson 1-D and Margalef) were calculated. Sediment contamination was evaluated according to VGQS (TEL and PEL). The results evidenced that the sediments of Facies 3 are highly contaminated since the beginning of RSG filling. Contamination caused significant decline of Testate
Citation:

Misailidis, M.L., Strikis, N.M., Figueira, R.C., Cordeiro, R.C., Strikis, P.C., Pregnolato, L.A., Duleba, W., 2017. Testate amoebae as bio-indicators of contamination by trace elements in the reservoir of Salto Grande Americana-SP, Brazil. Journal of Sedimentary Environments, 2 (4): 283300.

amoebae populations dimension and diversity. In sedimentary facies with lower concentrations of trace elements diversity and size of Testate amoebae populations are higher and are composed of different species. The results of this work indicate that Testate amoebae populations showed differentiated responses to different environmental conditions. So, these amoeboid protists can be considered good indicators of pollution caused by trace elements in fresh water aquatic environments.

Keywords: Trace Elements. Testate amoebae. BioIndicators. Pollutants. Reservoir. 


\section{Introduction}

The Reservoir of Salto Grande (RSG) is located in the municipality of Americana, São Paulo State, Southeastern of Brazil (Fig. 1). It was built to provide electric energy supply to industries of the region and to develop local economy (Espíndola et al., 2004). It began to operate in 1950 and today its electricity production has ceased due to the use of part of the water of the Atibaia watershed, where it is located, to supply the city of São Paulo. The Atibaia River is the main contributor to the reservoir. The RSG receives domestic and industrial sewage of 20 cities, in the highly industrialized Campinas Metropolitan Region, including for instance petrochemical, textile, fertilizer, pharmaceutical and food industries. Also, agriculture (sugar cane and fruits plantation, livestock) is very expressive on land close to the dam and along the watershed of the Atibaia River (Espíndola et al., 2004; Fonseca and Matias, 2014). So, since the 50's the RSG experienced an input of heavy polluted water that accompanied the growth of the Campinas Metropolitan Region.

\subsection{Testate amoebae}

The thecamoebians can be defined as a paraphyletic group of amoeboid protozoa, endowed with shells, placed in the Super Group Amebozoa, Group Tubilinea, Sub-Group Testate, Family Arcellenidea (Adl et al., 2005).

Thecamoebians are known in the fossil record since 800 million years, over a long period of Earth's History (Porter et al., 2003). Its successful evolutionary history should be due to the alternation of generations, sexual reproduction alternated with asexual one. This type of life cycle is well known in some species such as Arcella vulgaris, Trinemalineare, Corythiondubium, Centropyxis orbicularis, Corythion delamarei (Raikov et al., 1989; Mignot and Raikov, 1992; Yudina and Sukhanova, 2000).

The Testate amoebae are protected by unilocular test (Medioli and Scott, 1983; Pchelin, 2010). Tests have the function of providing mechanical protection and resistance against predation and adverse environmental conditions (Booth, 2001).

Thecamoebians are found in different latitudes and environments and therefore they are considered cosmopolitan (Pénard, 1902; Medioli and Scott, 1983; Finlay et al., 1996; Cruz, 2004). Pénard (1902) and Decoître (1953) proposed several dispersal mechanisms, such as birds, aerosol events and river currents. Their tests can be classified as autogeneic or xenogeneic. The former tests are secreted by the organism itself and are smooth and proteinic, and may be endowed with siliceous or, rarely, calcareous plaques. These thecamoebians are hardly preserved in the fossiliferous record.

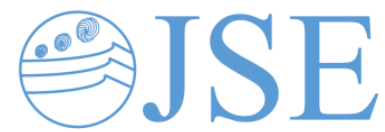

RESEARCH PAPER

Xenogeneic tests are formed by agglutination of particles (e.g., diatom frustules, quartz grains and other silicate mineral particles) on autogeneic cement. Unlike the autogeneic, they are resistant to low $\mathrm{pH}$ conditions, being often fossilized (Medioli and Scott 1988; Török, 2001; Gomes e Souza, 2008).

Thecamoebians have different sizes $(10 \mu \mathrm{m}$ to $900 \mu \mathrm{m})$ and shapes. They are mostly classified by their test morphology. According to Gomes and Souza (2008), Testate amoebae can present variations in their shape and size, depending on the environment and/or biotic and/or abiotic stress where they live. Many works on the ecology of the Thecamoebians mention several correlations of these organisms with their habitat. And they point to different interactions relating morphology, size, abundance and richness of the species with the environment (Lansac-Tôha et al., 1999; Duleba et al., 2004; Ferreira et al., 2006; Alves et al., 2007).

Testate amoebae have been used as bio-indicators of polluted sediments in rivers and lakes worldwide (Dias-Britto et al., 1988; Eichlerand Bonetti, 1995; Patterson et al., 1996; Duleba, 1999; Oliveira 1999; Patterson and Kumar, 2000 a, b; Booth 2001; Onianwa, 2001; Duleba et al., 2005; Xu et al. 2005; Nguyen-Vieta et al., 2008; Meyer et al., 2012.

Currently due to concerns about the impacts of climate change, especially about water conditions, the use of ecological indicators as an instrument to be applied in water quality monitoring programs becomes urgent.

\subsection{Trace elements}

Trace elements are serious contaminants of sediments and, in some cases, can be mobilized to the water column becoming a threat to the biota (Esteves, 2011). Once they have accumulative effect in the food chain their effects will eventually reach humans, through consumption of fish and other animals (Guilherme et al., 2005; Esteves, 2011).

Several features may influence trace elements mobilization, which vary from biotic, such as natural chelator substances, to abiotic factors such as synthetic chelators substances, $\mathrm{pH}$ variations and degree of eutrophication Jenne, 1968; Zitko and Carson, 1972; Chau and Shiomi, 1972; Lockwood and Chen, 1973).

\subsection{The main goals}

In this study, the variations of Thecamoebians populations were related to the variations of trace elements concentrations (As, $\mathrm{Cr}, \mathrm{Cu}, \mathrm{Fe}, \mathrm{Mn}, \mathrm{Ni}, \mathrm{Pb}, \mathrm{Sc}$ and $\mathrm{Zn}$; Sc was used to normalize the elements concentrations) and sediments grain size, aiming to test the hypothesis of these organism's populations and communities are bioindicators of pollution. 


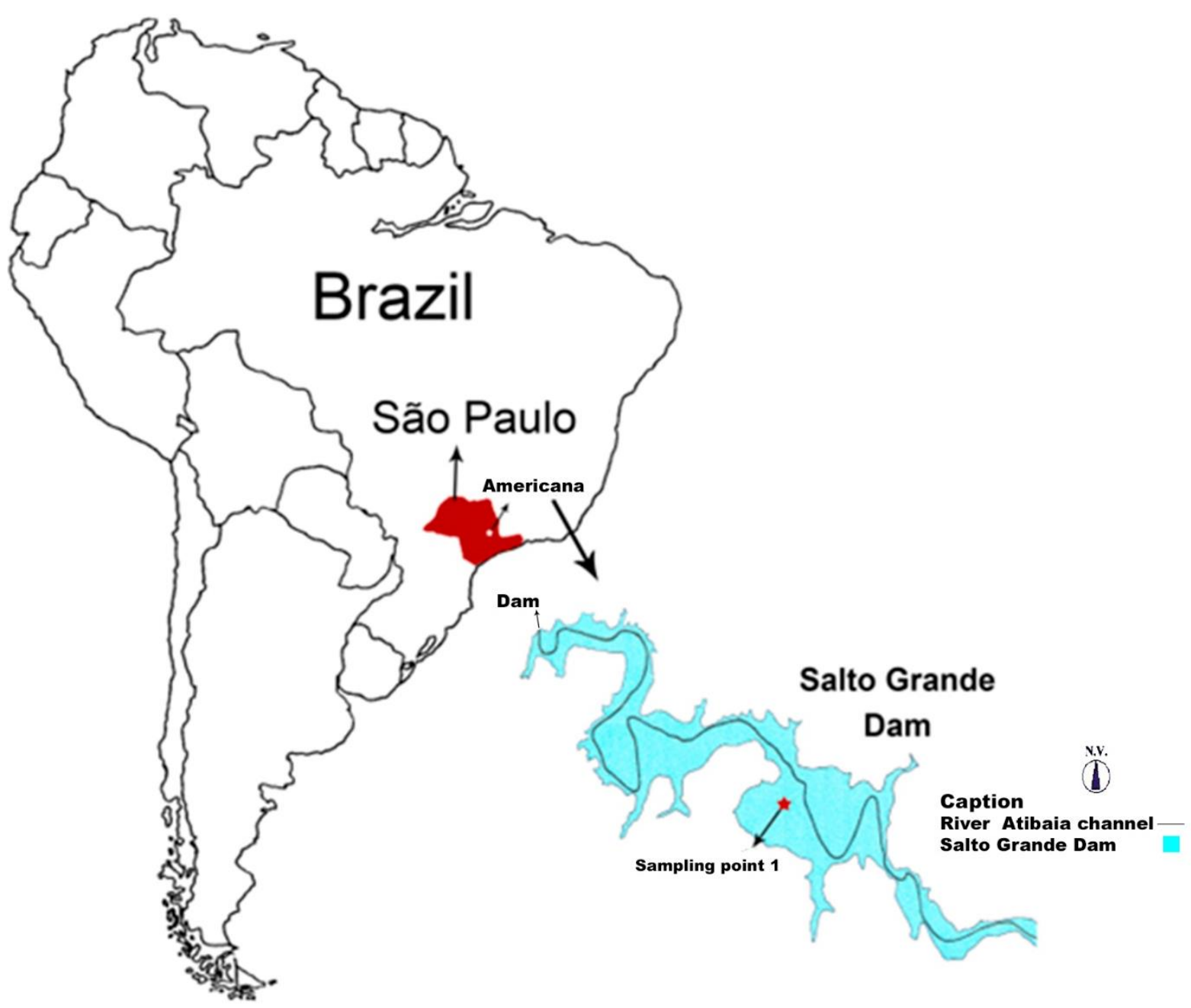

Fig. 1. Sampling point (Red Star) in the Reservoir of Salto.

\section{Geological setting of the study area}

The Reservoir of Salto Grande (RSG) is located in the municipality of Americana, São Paulo State, Southeastern of Brazil (22 $44^{\prime} \mathrm{S}$ and $47^{\circ} 19^{\prime} \mathrm{W}$; Fig. 1). The RSG is located in the São Paulo peripheral depression in the middle Tietê area and is part of the Piracicaba, Capivari and Jundiai river basin, formed by the damming of the Atibaia River. The Atibaia River, the main tributary of the reservoir, is born from the confluence of the Atibainha and Cachoeira rivers, both sources of the Greater São Paulo Metropolitan Region and are the main constituents of the Cantareira System.

The Atibaia River runs a length of $154 \mathrm{~km}$ until its impoundment, attending 20 municipalities (Fig. 1). Along its course, the river is influenced by twelve tributaries. At the head of the Atibaia River, starting from the municipality of Nazaré Paulista, the Atibaia river intersects metamorphic geological units associated to deformed sequences of the upper Neoproterozoic. The lithology comprises ortho and para-derived gneisses and migmatites, belonging to the Vargínia-Guaxupé complex, in addition to intrusive granites of several ages.

The Atibaia River runs a stretch of approximately $133 \mathrm{~km}$ ( $77 \%$ of its extension to the dam) in crystalline units of the Precambrian basement. At the municipality of Campinas (near the dam), this river reaches the Paleozoic sedimentary units of the Paraná Basin, represented by sandstones and shales of the Itararé Group and basalts of the Serra Geral Formation. From this point, the river runs approximately 40 $\mathrm{km}$ until reaching the dam, at the municipality of Americana (Fonseca and Matias, 2014).

\section{Material and methods}

A sediment core of $235 \mathrm{~cm}$ was taken from the RSG $\left(22^{\circ} 43^{\prime} 29.4^{\prime \prime} \mathrm{S}\right.$ and $\left.47^{\circ} 13^{\prime} 51.3^{\prime \prime} \mathrm{W}\right)$ at a point shown in Figure 1 , approximately $1300 \mathrm{~m}$ from the west bank and $900 \mathrm{~m}$ from 
the east bank and $14 \mathrm{~m}$ deep. The core was collected during the dry season on May 27, 2015, by means of witness of gravity, following the sampling technique of SubGeo Commerce of Nautical Equipment and Submarine Technical Services. In this technique, the core collection is performed from the percussion of a weight which is thrown against a transverse rod attached to the sampler tube. The progressive elevation of this weight as well as the removal of the toss was controlled by divers. The transport of the core was carried out with extreme care to avoid contamination of the lower layers by elements of the upper layers that could percolate between the sediments. The core was taken to the laboratory of the Instituto Oceanográfico of Universidade of São Paulo (IO-USP) where it was open and sliced; the first slice, beginning at the depth of $8 \mathrm{~cm}$ until $16 \mathrm{~cm}$, the first centimeters were sliced every $8 \mathrm{~cm}$ due to fluidity presented by sediments, after $16 \mathrm{~cm}$ it was sliced every $4 \mathrm{~cm}$ until 24 $\mathrm{cm}$ and in sequence, to the base of the core, it was sliced every $2 \mathrm{~cm}$.

The slices were put in plastic vials and taken to the refrigerator $\left(4^{\circ} \mathrm{C}\right)$ until lyophilizing. The vials were previously washed with "extran" (MERK), rinsed in osmolized water and then submerged into $\mathrm{HNO}_{3} 10 \%$ solution for 24 hours and dried.

Chemical analysis to detect trace elements were carried out at the Laboratório de Química Inorgânica Marinha (LaQI Mar), from IO-USP. A partial digestion of the sediments was carried out following the protocol 3050B (USEPA, 1996). To quantify trace elements a ICP-OES model MPX 710-ES from VARIAN was used according to the method SW-846 USEPA 6010c (USEPA, 2000). Concentrations levels of As, $\mathrm{Cr}, \mathrm{Cu}, \mathrm{Fe}, \mathrm{Mn}, \mathrm{Ni}, \mathrm{Pb}$ and $\mathrm{Zn}$ were analyzed. Concentrations were calculated according to the formula (Skoog et al., 1998):

$$
[\mathrm{E}]=\frac{V p \times F d \times V f}{m}
$$

Where:

$$
\begin{aligned}
& \text { [E]: Trace element concentration } \mathrm{mg} / \mathrm{kg} \\
& V p: \text { Value obtained by the plasma, } m g / l \\
& \text { Fd: Dilution factor } \\
& V f: \text { Final volume, } m l \\
& m: \text { mass, } g
\end{aligned}
$$

Each sample was measured 3 times and the values correspond to the mean of the measures.

Granulometric analyses were carried out at the Laboratório de Sedimentologia, of Instituto de Geociências, of Universidade de São Paulo (IGC-USP). The equipment used was a Mastersizer 2000 from Malvern. The degree of sediments selection was classified according to Folk and Ward (1957). The methodology initially consists of preparing the sample: macerate and homogenize the sediment and then remove organic material and carbonates by attack with hydrogen peroxide. The sample is then oven dried and homogenized. An aliquot of 2 grams of the dry sediment in 1 liter of deionized water under constant stirring and 5 drops of dispersant (sodium pyrophosphate) are added, keeping the system under ultrasound to disaggregate the particles which are directed to a reader of laser diffraction. The data obtained by Malvem are sent to a program that expresses the measured values graphically, using the percentages of different granulometric fractions.

In order to evaluate the anthropic intervention in the RSG system, demographic growth data were compared with the concentrations of trace elements. Population growth data were obtained through published IBGE-2014 reports

Testate amoebae species were identified using a Zeiss stereomicroscope with a $3.5 \mathrm{Mb}$ digital camera. Photos were taken in order to enable measurements, when necessary. As the communities of Testate amoebae represent thanatocoenoses, the only way to taxonomically identify a species is through its morphology, once no DNA or RNA molecular information is available. The organism's identification was based on the morphology of Testate amoebae and using as reference the work of several authors (Asioli et al., 1996; Lahr, 2006; Gomes e Souza, 2008). Although this is not the most ideal scenario to detect the different species, information obtained through thanatocoenoses, in turn, allows the detection of biotic and abiotic variations on a broader temporal scale (Duleba et al., 2004).

Density was calculated using the number of tests per $10 \mathrm{cc}$. Simpson 1-D and Margalef $\mathrm{D}_{\mathrm{Mg}}$ were also determined in order to infer the homogeneity of Testate amoebae communities and to access the species richness, respectively, and were used as diversity indices.

$\mathrm{D}_{\mathrm{Mg}}$ was calculated according to the following formula:

$D_{\mathrm{Mg}}=\frac{(S-1)}{\ln N}$

Where,

$D_{M g}=$ Species richness

$S=$ Number of sampled species

$N=$ Total number of individuals in a population.

D was calculated according to the formula:

$$
D=\sum\left(\frac{n_{i}\left[n_{i}-1\right]}{N[N-1]}\right)
$$

Where,

$n_{i}=$ number of specimens in the $i_{\text {th }}$ species.

$N=$ Total number of specimens. 
Simpson index is thus 1-D in order to facilitate the interpretation of data. The highest values of this index are indicative of more homogeneous communities (Magurran, 2004).

In order to evaluate the degree of sediments contamination the sediment quality guide values adopted by the Brazilian legislation, CONAMA $\mathrm{n}^{\circ} 454$ of November $1^{\text {st }}$ 2012 to dredge sediments (CONAMA, 2012), which is based on the Canadian classification of pollutants (TEL and PEL) was used (Canadian Environmental Quality GuidelinesCCME, Summary Table; http://st-ts.ccme.ca/en/index.html), so TEL values (Threshold Effect Level) contaminant levels under which no harm is expected to the biota and PEL (Probable Effect Level) contaminant levels in which it is expected to occur adverse biological effects.

\subsection{Statistical analyzes}

Principal Correspondence Analysis (PCoA) and Pearson correlation ( $\mathrm{r}$ ) from the main component analysis (PCoA) were used to identify patterns of association between the analyzed variables (granulometry, trace elements and Testate amoebae species). Also, Non - Metric Multidimensional Scaling (NMMDS) was performed based on diversity, richness and density indices, allowing the use of any type of scale between the analyzed variables and the species of Testate amoebae. When the obtained stress values are $<0.05$, they indicate very low incompatibility between the classification order of data distance. But values $>0.3$ indicate an arbitrary ordering which makes very difficult the results interpretation. Both PCoA and NMMDS are ordination analyzes that allow the exploration of environmental variables in a gradient searching that can explain the distribution of the species along the gradient.

The PAST 3.12 program (Hammer et al., 2001) was used to perform the Grouping, PCoA and NMMDS analysis. Regarding NMMDS, we chose to use the Gower method, as the variables are on different scales.

\section{Results}

Grain size curves of sand, silt and clay fractions are shown in Figure 2. Sand, silt and clay fraction represent, in average, $3.5 \%, 71.2 \%$ and $25.3 \%$ respectively, in the upper $160 \mathrm{~cm}$ of the sediment core as shown in Figure 2.

The results of trace elements concentrations measured in the sediments along the studied core are presented in Table 1 and plotted in Figure 3. Concentrations varied for: As between 2.97 - $12.16 \mathrm{mg} / \mathrm{kg}$; Cr between 16.5 - $90.8 \mathrm{mg} / \mathrm{kg}$; Cu between 38 - 522 mg/kg; Fe between 49 - 71910 mg/kg; Mn between $52.6-1200 \mathrm{mg} / \mathrm{kg}$; $\mathrm{Ni}$ between $6.50-35.72$ $\mathrm{mg} / \mathrm{kg}$; Pb between $11.78-38.51 \mathrm{mg} / \mathrm{kg}$ and; $\mathrm{Zn}$ between 35 $-164 \mathrm{mg} / \mathrm{kg}$.
Facies 3 (154 - $94 \mathrm{~cm}$ depth) was the most representative in terms of contamination since it keeps the highest concentration values of all analyzed elements: As- $12 \mathrm{mg} / \mathrm{kg}$; $\mathrm{Cr}-90$ mg/kg; Cu - 522 mg/kg; Fe - 64 g/kg; Mn - 1200 $\mathrm{mg} / \mathrm{kg}: \mathrm{Ni}-36 \mathrm{mg} / \mathrm{kg} ; \mathrm{Pb}-38 \mathrm{mg} / \mathrm{kg}$ and; $\mathrm{Zn}-164 \mathrm{mg} / \mathrm{kg}$.

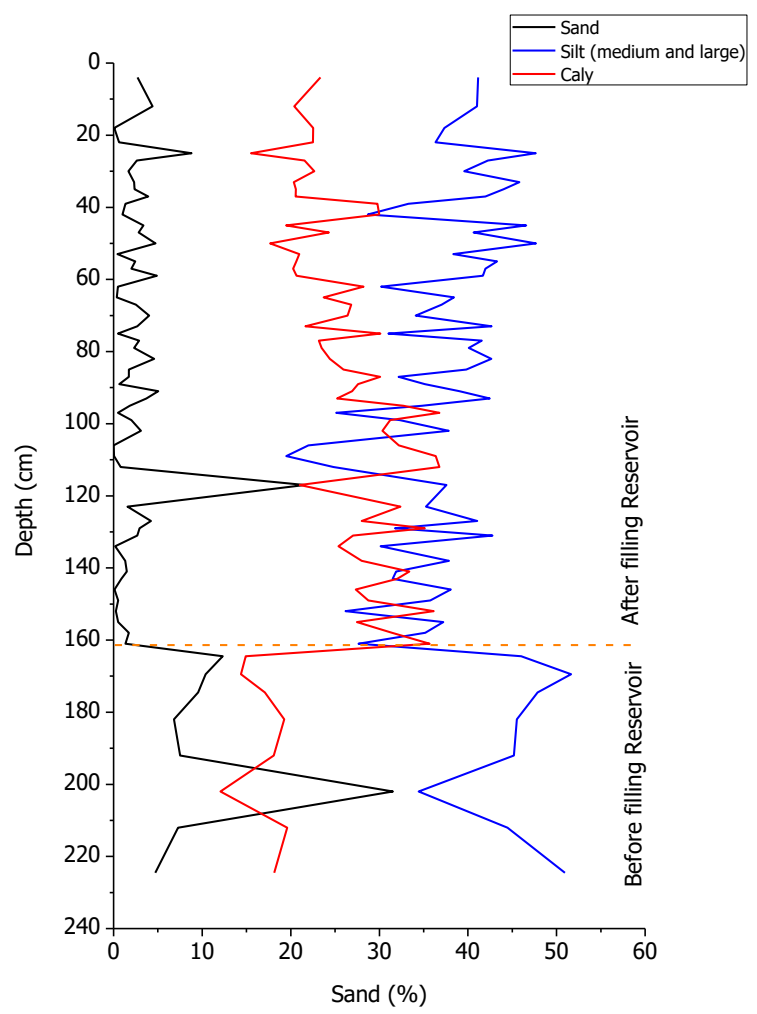

Fig. 2. Percentage of silt, clay and sand in contrast to depth of sediments in the core. Dotted traced line represent the moment at which the RSG was filled.

The relations of trace elements and grain size are shown in PCoA analysis (Appendix 1), where the first axis explains $95.86 \%$ of the variance of the majority of trace elements and clay and sand fractions is mainly related to coordinate 2 .

Pearson correlations ( $\mathrm{r}$ ) between grain size and trace elements are shown in Table 2. The majority of trace elements have high correlation with clay fraction. Arsenic, $\mathrm{Cr}, \mathrm{Cu}$ and $\mathrm{Pb}$ presents the highest correlation with clay fraction and; $\mathrm{Zn}$ has the highest correlation with sand fraction; only Mn shows high correlation with silt.

In Table 4, colored Facies indicate changes in Testate amoebae community composition. Figure 6 correlates the density, richness and abundance of Testate amoebae populations with textural characteristics of different sedimentary facies of the core.

Facies 1 (230-177 cm deep): gradual transition to clay levels well consolidated with light grey color with varied texture formed by spots of ocher color followed by a mottled aspect. Facies 1 is characterized by the total absence of thecamoebians. 
Tab. 1. Trace elements concentrations $(\mathrm{mg} / \mathrm{kg})$ and TOC percentage $(\%)$ along the studied core. Values in red indicate concentrations above PEL and TEL.

\begin{tabular}{|c|c|c|c|c|c|c|c|c|c|c|}
\hline $\begin{array}{l}\text { Depth } \\
(\mathrm{cm})\end{array}$ & $\begin{array}{c}\text { As } \\
\mathrm{mg} / \mathrm{Kg}\end{array}$ & $\begin{array}{c}\mathrm{Cd} \\
\mathrm{mg} / \mathrm{Kg}\end{array}$ & $\begin{array}{c}\mathrm{Cr} \\
\mathrm{mg} / \mathrm{Kg}\end{array}$ & $\begin{array}{c}\mathrm{Cu} \\
\mathrm{mg} / \mathrm{Kg}\end{array}$ & $\begin{array}{c}\mathrm{Ni} \\
\mathrm{mg} / \mathrm{Kg}\end{array}$ & $\begin{array}{c}\mathrm{Pb} \\
\mathrm{mg} / \mathrm{Kg}\end{array}$ & $\begin{array}{c}\mathrm{Zn} \\
\mathrm{mg} / \mathrm{Kg}\end{array}$ & $\begin{array}{c}\mathrm{Fe} \\
\mathrm{mg} / \mathrm{Kg}\end{array}$ & $\begin{array}{c}\mathrm{Mn} \\
\mathrm{mg} / \mathrm{Kg}\end{array}$ & $\begin{array}{c}\text { TOC } \\
\%\end{array}$ \\
\hline 8 & 4.3 & 0.4 & 16.6 & 38.7 & 6.6 & 11.8 & 57.1 & 55299.0 & 690.3 & 3.4 \\
\hline 16 & 3.9 & 0.4 & 21.9 & 53.6 & 12.6 & 14.4 & 82.6 & 63590.0 & 825.1 & 2.7 \\
\hline 20 & 4.0 & 0.5 & 25.7 & 58.2 & 13.9 & 16.1 & 112.5 & 60001.0 & 920.6 & 2.0 \\
\hline 24 & 3.3 & 0.5 & 25.5 & 54.1 & 13.2 & 16.6 & 107.9 & 58861.0 & 760.7 & 2.2 \\
\hline 26 & 3.3 & 0.4 & 16.9 & 48.5 & 8.0 & 12.6 & 81.9 & 59096.0 & 867.0 & 3.2 \\
\hline 28 & 4.2 & 0.4 & 20.4 & 44.2 & 11.4 & 14.0 & 89.5 & 57426.0 & 768.8 & 2.6 \\
\hline 32 & 4.3 & 0.5 & 25.2 & 53.2 & 14.9 & 16.3 & 92.1 & 54782.0 & 968.0 & 2.6 \\
\hline 34 & 3.4 & 0.3 & 18.3 & 38.1 & 8.5 & 13.0 & 64.3 & 49259.0 & 691.7 & 2.0 \\
\hline 36 & 4.3 & 0.4 & 23.4 & 47.7 & 12.0 & 14.1 & 79.7 & 57808.0 & 771.0 & 2.5 \\
\hline 38 & 4.7 & 0.6 & 28.5 & 56.6 & 16.3 & 15.6 & 87.9 & 56630.0 & 939.5 & 3.3 \\
\hline 40 & 4.2 & 0.5 & 29.0 & 51.7 & 14.2 & 16.0 & 85.5 & 63499.0 & 799.7 & 1.5 \\
\hline 44 & 3.9 & 0.5 & 26.9 & 48.4 & 12.5 & 15.5 & 95.9 & 58040.0 & 867.5 & 2.3 \\
\hline 46 & 3.8 & 0.4 & 22.8 & 42.9 & 9.4 & 13.4 & 90.1 & 57677.0 & 851.6 & 2.6 \\
\hline 48 & 4.9 & 0.6 & 30.6 & 60.2 & 15.9 & 17.3 & 111.4 & 56495.0 & 891.2 & 1.7 \\
\hline 52 & 5.1 & 0.6 & 25.7 & 59.0 & 14.8 & 16.3 & 108.5 & 55506.0 & 882.1 & 2.5 \\
\hline 54 & 3.0 & 0.5 & 20.0 & 39.7 & 8.3 & 14.0 & 72.2 & 62516.0 & 1002.7 & 2.1 \\
\hline 56 & 3.7 & 3.2 & 21.0 & 47.2 & 11.6 & 13.8 & 82.7 & 57974.0 & 869.2 & 1.8 \\
\hline 58 & 5.6 & 0.6 & 28.7 & 59.0 & 17.6 & 16.7 & 104.3 & 57038.0 & 888.7 & 2.6 \\
\hline 60 & 3.8 & 0.6 & 22.3 & 46.0 & 13.4 & 15.1 & 85.6 & 56699.0 & 887.3 & 2.3 \\
\hline 64 & 4.9 & 0.5 & 26.5 & 48.8 & 13.3 & 16.3 & 90.9 & 58963.0 & 1176.9 & 2.3 \\
\hline 66 & 3.3 & 0.4 & 18.5 & 39.1 & 7.6 & 13.3 & 66.1 & 57380.0 & 928.1 & 2.1 \\
\hline 68 & 6.5 & 0.7 & 27.4 & 62.5 & 15.5 & 17.5 & 105.4 & 62707.0 & 972.8 & 2.5 \\
\hline 72 & 5.7 & 2.3 & 24.8 & 51.7 & 11.6 & 16.3 & 77.7 & 59857.0 & 1127.0 & 3.6 \\
\hline 74 & 4.7 & 0.4 & 19.4 & 39.8 & 8.7 & 13.6 & 60.9 & 54578.0 & 809.5 & 2.4 \\
\hline 76 & 4.1 & 2.7 & 21.7 & 43.1 & 9.6 & 15.8 & 69.4 & 55151.0 & 1135.7 & 1.7 \\
\hline 78 & 4.9 & 2.3 & 20.3 & 47.3 & 11.0 & 15.5 & 67.5 & 55433.0 & 1103.4 & 2.6 \\
\hline 80 & 5.5 & 0.5 & 27.3 & 49.5 & 16.3 & 18.5 & 80.6 & 58978.0 & 851.8 & 2.9 \\
\hline 84 & 5.5 & 0.7 & 29.2 & 59.2 & 19.1 & 20.4 & 94.7 & 71910.0 & 1110.7 & 1.9 \\
\hline 86 & 4.7 & 2.1 & 22.0 & 50.9 & 12.2 & 18.4 & 70.4 & 58035.0 & 843.5 & 2.8 \\
\hline 88 & 5.5 & 0.6 & 25.7 & 65.9 & 16.2 & 19.7 & 82.0 & 56011.0 & 878.9 & 1.5 \\
\hline 90 & 3.8 & 3.2 & 16.5 & 49.8 & 7.7 & 14.7 & 47.1 & 55423.0 & 729.3 & 1.4 \\
\hline 92 & 5.2 & 2.3 & 19.9 & 61.6 & 10.8 & 17.4 & 60.5 & 59049.0 & 869.0 & 2.3 \\
\hline 94 & 4.1 & 3.6 & 22.2 & 71.5 & 11.2 & 16.9 & 60.6 & 57576.0 & 960.9 & 4.5 \\
\hline 96 & 6.0 & 0.7 & 42.4 & 154.9 & 20.8 & 21.7 & 87.6 & 63710.0 & 912.5 & 2.1 \\
\hline 100 & 4.1 & 3.8 & 21.8 & 209.2 & 12.8 & 15.6 & 57.9 & 54508.0 & 527.6 & 3.1 \\
\hline 104 & 4.9 & 5.0 & 27.1 & 331.6 & 8.8 & 19.0 & 68.6 & 59607.0 & 633.8 & 2.9 \\
\hline 108 & 5.8 & 22.0 & 45.6 & 212.4 & 15.9 & 36.1 & 96.8 & 55840.0 & 1199.9 & 3.2 \\
\hline 114 & 5.3 & 7.1 & 47.0 & 220.4 & 24.7 & 29.2 & 89.1 & 60295.0 & 752.0 & 2.0 \\
\hline 120 & 12.2 & 6.8 & 72.1 & 522.2 & 35.7 & 38.5 & 163.6 & 59019.0 & 324.9 & 2.3 \\
\hline 126 & 7.9 & 9.4 & 60.9 & 301.2 & 20.1 & 29.3 & 80.6 & 56213.0 & 589.8 & 3.2 \\
\hline 128 & 8.3 & 6.6 & 90.9 & 414.0 & 21.6 & 32.0 & 90.3 & 60241.0 & 441.1 & 2.3 \\
\hline
\end{tabular}


Tab. 1. (cont.) Trace elements concentrations $(\mathrm{mg} / \mathrm{kg})$ and TOC percentage (\%) along the studied core. Values in red indicate concentrations above PEL and TEL.

\begin{tabular}{|c|c|c|c|c|c|c|c|c|c|c|}
\hline $\begin{array}{l}\text { Depth } \\
\text { (cm) }\end{array}$ & $\begin{array}{c}\text { As } \\
\mathrm{mg} / \mathrm{Kg}\end{array}$ & $\begin{array}{c}\mathrm{Cd} \\
\mathrm{mg} / \mathrm{Kg}\end{array}$ & $\begin{array}{c}\mathrm{Cr} \\
\mathrm{mg} / \mathrm{Kg}\end{array}$ & $\begin{array}{c}\mathrm{Cu} \\
\mathrm{mg} / \mathrm{Kg}\end{array}$ & $\begin{array}{c}\mathrm{Ni} \\
\mathrm{mg} / \mathrm{Kg}\end{array}$ & $\begin{array}{c}\mathrm{Pb} \\
\mathrm{mg} / \mathrm{Kg}\end{array}$ & $\begin{array}{c}\mathrm{Zn} \\
\mathrm{mg} / \mathrm{Kg}\end{array}$ & $\begin{array}{c}\mathrm{Fe} \\
\mathrm{mg} / \mathrm{Kg}\end{array}$ & $\begin{array}{c}\mathrm{Mn} \\
\mathrm{mg} / \mathrm{Kg}\end{array}$ & $\begin{array}{c}\text { TOC } \\
\%\end{array}$ \\
\hline 132 & 10.7 & 16.8 & 70.0 & 409.3 & 20.6 & 37.2 & 96.2 & 59162.0 & 360.7 & 2.1 \\
\hline 136 & 4.4 & 10.7 & 34.5 & 164.4 & 15.9 & 22.3 & 80.8 & 60433.0 & 781.6 & 3.1 \\
\hline 140 & 7.8 & 6.7 & 46.1 & 226.3 & 21.6 & 29.8 & 100.7 & 64329.0 & 604.7 & 4.8 \\
\hline 148 & 5.9 & 6.2 & 42.2 & 67.2 & 16.0 & 24.5 & 128.4 & 61964.0 & 608.3 & 5.3 \\
\hline 154 & 5.6 & 4.5 & 40.6 & 46.6 & 11.8 & 23.7 & 120.9 & 65459.0 & 1095.2 & 3.1 \\
\hline 162 & 6.7 & 4.9 & 42.9 & 59.7 & 13.9 & 24.1 & 79.7 & 58027.0 & 365.8 & 3.1 \\
\hline 167 & 4.6 & 4.8 & 32.6 & 44.3 & 10.4 & 20.9 & 51.6 & 25775.0 & 164.3 & 1.1 \\
\hline 177 & 3.3 & 4.3 & 30.0 & 38.4 & 9.7 & 20.6 & 35.7 & 16268.0 & 101.0 & 0.8 \\
\hline 233 & 6.3 & 9.6 & 33.2 & 79.7 & 10.4 & 22.1 & 49.3 & 26179.0 & 52.6 & 0.9 \\
\hline
\end{tabular}
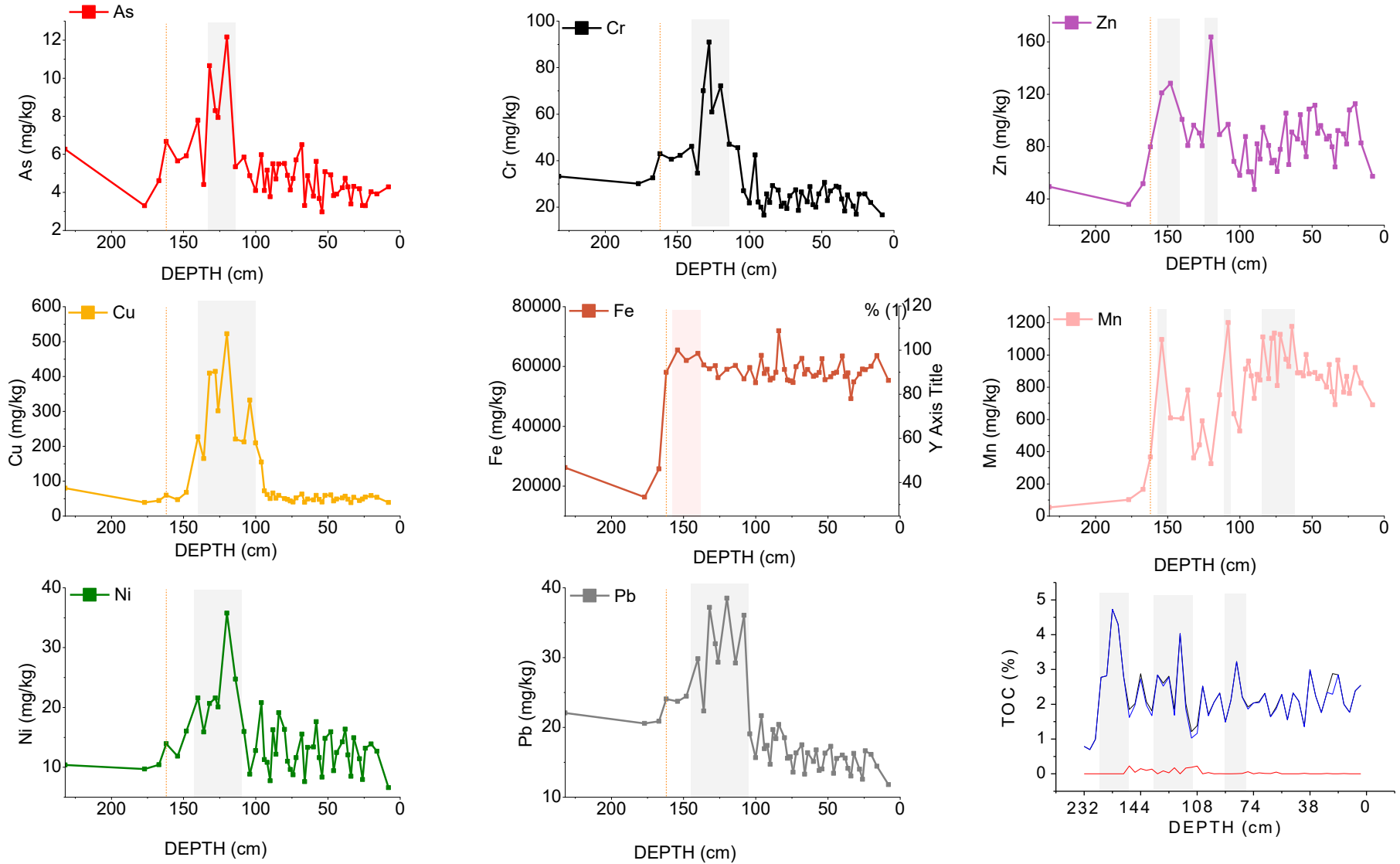

Fig. 3. Trace elements against depth. TOC (black line) organic carbon (blue line) and inorganic carbon (red line) concentrations against depth. Dotted vertical lines represent the moment of RSG filling.

Facies 2 (177-154 cm deep): erosion unconformity marking the contact between the facies of mud-clay grey color to the facies with a clearer color gradation in direction to the base of the core, with high concentration of roots that decrease towards the base, suggestive of soil; this facies characterizes the beginning of the presence of thecamoebians, the most prevalent species are Difflugia corona, Difflugia oblonga, Difflugia gramen and Arcella gibbosa.

Facies 3 (154-94 cm deep): gradual transition to a more consolidated and more homogeneous sediment with a clearer brown color; it is possible to see a subtle plan-parallel stratification; it presents higher index of contamination by 
metals; the dominant species are Arcella megastoma, A. gibbosa and D. corona.

The Facies 4 (94-42 cm deep): is the most representative facies of the core. It is composed by more consolidated sediments; it has plan-parallel stratification at centimetric level, with intercalations of black and brown mud; it has greater abundance, richness and diversity of the of Testate amoebae populations, which are mainly composed by
Centropyxis aculeata discoid and D. corona followed by $A$. megastoma, D. gramen and Netzelia oviformis.

Facies 5 (34-8 $\mathrm{cm}$ deep): is composed by very fluid unconsolidated sediments, with dark brown color; near the top is characterized by a new decline in the abundance, diversity and richness of the Testate amoebae populations; the predominant species is $C$. aculeata discoide. The species found in the present work are shown in Figures 7 and 8.

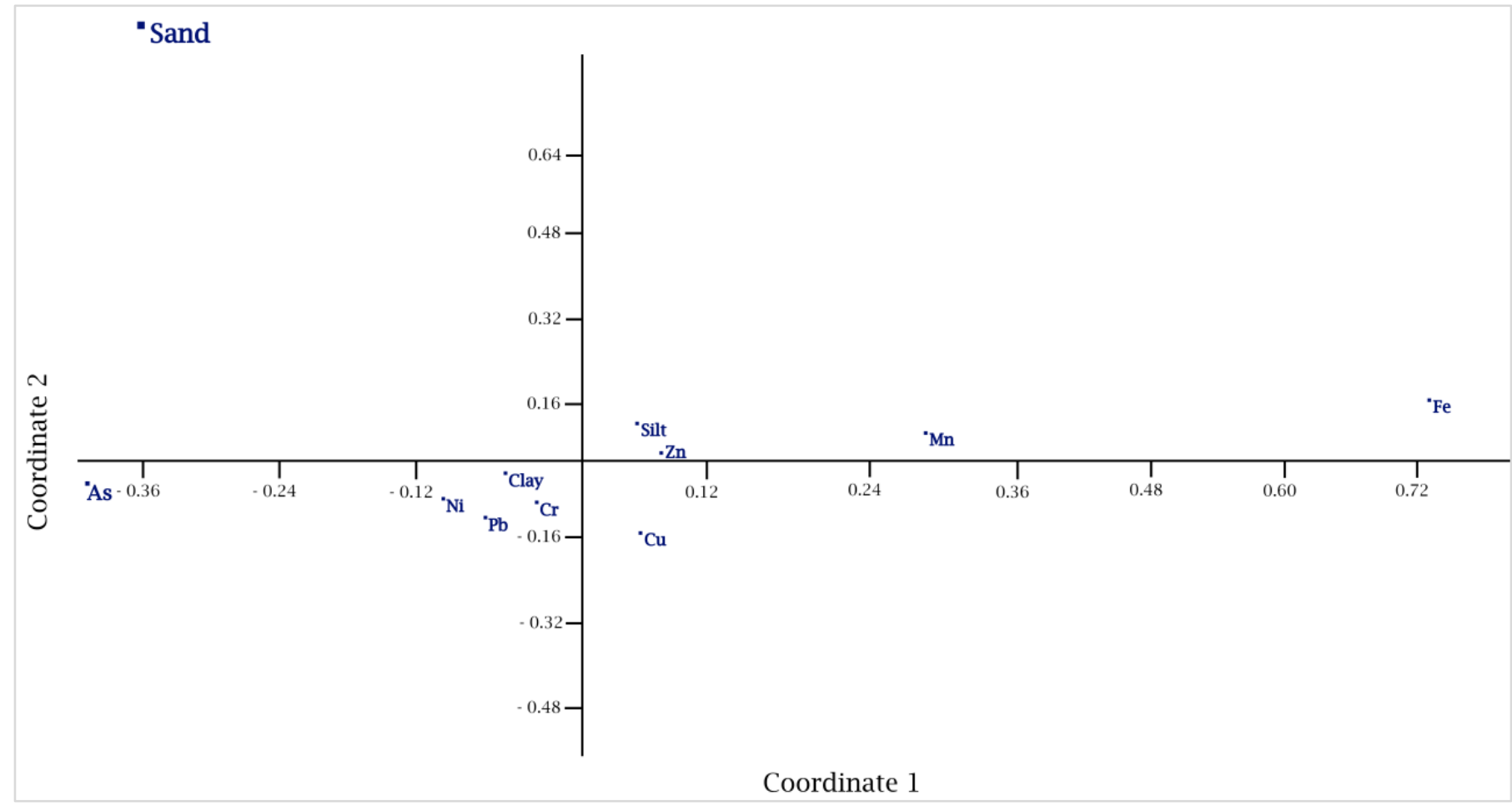

Fig. 4. Graphic representation of environmental variables (trace elements and grain size) by PCoA. Values is in $\log _{2}$.

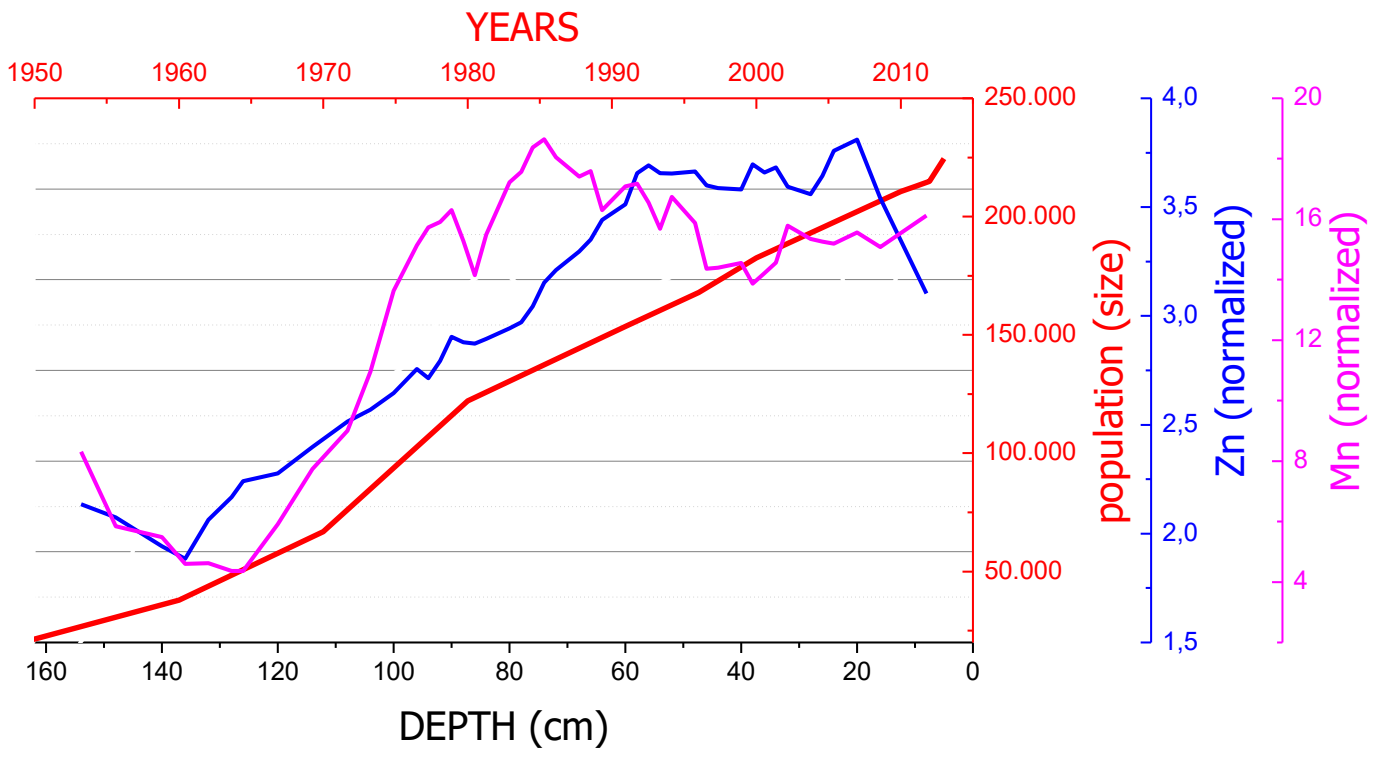

Fig. 5. Demographic growth curve followed by the concentration curves of $\mathrm{Mn}$ and $\mathrm{Zn} \mathrm{mg} / \mathrm{kg}$. 
The depth plot of $\mathrm{As}, \mathrm{Cr}, \mathrm{Cu}, \mathrm{Ni}, \mathrm{Pb}$ and $\mathrm{Zn}$ and the number of Testate amoebae specimens are shown in Figure 9. The Pearson correlations between Testate amoebae abundance of specimens and potentially toxic trace elements, such as $\mathrm{As}, \mathrm{Cr}, \mathrm{Cu}, \mathrm{Ni}, \mathrm{Pb}$ and $\mathrm{Zn}$ showed that the most negative correlations occurred with $\mathrm{Cr}, \mathrm{Cu}$ and $\mathrm{Pb}$ (Table 5).

The NMMDS plot (Fig. 10) correlates the density, richness and abundance of the populations of Testate amoebae with trace elements concentrations and core depth. The variables of Table 4 were used to generate the NMMDS plot; the obtained stress value was 0.06204 (Fig. 11). It shows that Facies 5 (red) and Facies 3 (purple) are overlapped as well as Facies 4 (blue) and 1 (green). This overlapped pattern of Facies is releted to the correlation between Testate amoebae populations distribution and trace elements concentrations distribution as suggested by the data in Table 5. This table shows negative Pearson correlation between number of specimens of Testate amoebae and trace elements concentration.

Tab. 2. Pearson $r$ between sand, silt and clay fractions and trace elements.

\begin{tabular}{lccc}
\hline \hline Variables & Sand & Silt & Clay \\
\hline \hline Sand & - & 0.02 & -0.03 \\
Silt & 0.02 & - & -0.94 \\
Clay & -0.03 & -0.94 & - \\
As & 0.39 & -0.61 & 0.67 \\
$\mathbf{C r}$ & 0.40 & -0.55 & 0.59 \\
$\mathbf{C u}$ & 0.59 & -0.5 & 0.55 \\
$\mathbf{N i}$ & 0.53 & -0.49 & 0.52 \\
$\mathbf{P b}$ & 0.38 & -0.67 & 0.71 \\
$\mathbf{Z n}$ & 0.20 & -0.16 & 0.03 \\
$\mathbf{F e}$ & -0.28 & -0.40 & 0.41 \\
$\mathbf{M n}$ & -0.27 & 0.44 & -0.52 \\
\hline
\end{tabular}

\section{Discussion}

In the present work is analyzed the composition of Testate amoebae, granulometry and geochemical data, obtained along the sediment core that covers a period of the flooding of the in the reservoir of Salto Grande (RSG; Fig. 1) in the municipality of Americana-SP, Brazil, until the present, a time spaning $\approx 65$ years. The splicing of the core followed a 2 -cm interval, practically an annual resolution, considering a sedimentation rate of $2 \mathrm{~cm} /$ year estimated for this area by Leite (2002).

Granulometric parameters presented small variation throughout the core. In the core section $230-170 \mathrm{~cm}$, the granulometric curves presented no oscillation, indicating a stable hydrodynamic environment. From $170 \mathrm{~cm}$ to the core top, the granulometric curves present variations of low amplitude, related probably to frequent meteorological and other disturbing events. The granulometric curves suggest the occurrence of four main disturbing events. The most representative event is recorded in the core section 170-160 $\mathrm{cm}$, where a strong inflection in the granulometric curves is observed, related to be the moment of the reservoir filling. All three events indicate an increase in fine sand and diminution of silt and shale. The granulometric analyzes of the RGS core showed predominance of silt-shale sediments (Fig. 2).

Sedimentary TOC content, depends on the amount od organic matter supplied to the bottom, deposited and preserved in the sediments. So, and although it is not correct to infer about the trophic state of a lacustrine system only based on the evaluation of the sedimentary carbon content, the obtained results in this wok allow to do some considerations on the contribution of the influx of nutrients to the RSG. In general, TOC concentrations are relatively lower (Table 1), than those obtained from other Dams of São Paulo state, such as Billings, Rasgão, Bariri, Barra Bonita, Promissão (Silveiro, 2003). Although tge RGS should not be considered a highly eutrophized environment, it is noteworthy that in the last 65 years of existence, the carbon values oscillated a lot probable due to the influx of terrigenous contributions, associated with river floods and the supply of macrophyte remains. According to Meyer et al. (2012), macrophytes are among the highest contributors of organic carbon in lake systems. Nevertheless, at specific intervals, it was detected a relation between the nutrients and the Testate amoebae population. For example, at Facies 3 (core section 154-94 cm), where conspicuous increase in the values of TOC and trace elements occurs, a deep decline in the abundance and richness of the Testate amoebae populations is observed, suggesting increased stress by contamination and excess of organic matter deposition in the sediments.

To evaluate the influence of anthropic activities on the RSG, a series of trace elements normalized by Sc were used (Table 1 and Fig. 3), the curves obtained show a marked event between 140-90 cm depth (Facies 3). In this core section, all the trace elements increase their concentration, except Mn, that presents lower concentration. From this level to the core top (Facies 4 and 5), the trace elements concentrations are moderate, suggesting periods of major intervention of public policies and social actions through ecological groups that took place in the 1980s and 1990s. Data of IBGE (2010) also corroborate this interpretation. They point to major investments in the treatment of domestic and industrial effluents by the municipalities of Atibaia river (main tributary of RSG). Concentrations of $\mathrm{Zn}$ and $\mathrm{Mn}$ has a gradual tendency to increase towards the core 
top. $\mathrm{Zn}$ is a chemical tracer indicative of contributions from soil leaching both in the surrounding area and in the drainage basin and industrial and domestic effluents contribution.

Trace elements such as $\mathrm{As}, \mathrm{Cr}, \mathrm{Cu}, \mathrm{Ni}$ and $\mathrm{Pb}$ present the highest concentrations in Facies 3. Toward the top of the sediment core: Facies 3 have moderate contamination by As, $\mathrm{Cr}, \mathrm{Ni}$ and $\mathrm{Pb}$; high contamination by $\mathrm{Cu}$ which raches 500 $\mathrm{mg} / \mathrm{kg}$; Facies 4 and 5 have more moderate contamination by trace elements; low contamination was found in the soil portion (Facies 1).

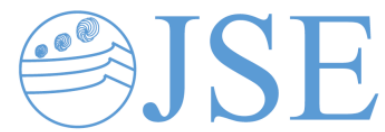

The high concentrations of $\mathrm{Cu}$ present in the sediments should be related to the intensive use of algicide to control cyanobacteria and macrophytes flowering and in agricultural activity as a pesticide (Bordeaux), in both cases in the form of $\mathrm{CuSO}_{4}$.

Thus, the use of the surrounding soil, population growth and variation of the rain rate exert a strong control of the contribution of $\mathrm{Cu}, \mathrm{Zn}$ and $\mathrm{Mn}$ in the RSG and reflect the contribution of the anthropic activities (Fig. 5).

Tab. 3a. Application of sediment quality guideline values according to CONAMA 454/2012 resolution for the section between 8-100 $\mathrm{cm}$. Values in $\mathrm{mg} / \mathrm{kg}$.

\begin{tabular}{cccccc} 
Elements & \multicolumn{2}{c}{ RSG $(\mathbf{0 - 1 0 0} \mathbf{c m})$} & TEL & PEL & World Shales \\
& Min & Max & & & \\
\hline As & 3.0 & 6.5 & $<5.9$ & 37 & 13 \\
$\mathrm{Cr}$ & 16.5 & 42.4 & $<37.3$ & 90 & 90 \\
$\mathrm{Cu}$ & 38 & 209 & $<35.7$ & 197 & 45 \\
$\mathrm{Fe}$ & 49259 & 71910 & SVR & SVR & 46.7 \\
$\mathrm{Mn}$ & 528 & 1177 & SVR & SVR & 850 \\
$\mathrm{Ni}$ & 6.6 & 20.8 & $<18.0$ & 35.9 & 68 \\
$\mathrm{~Pb}$ & 11.8 & 21.7 & $<35.0$ & 91.3 & 20 \\
$\mathrm{Zn}$ & 47.1 & 112.5 & $<123$ & 315 & 95
\end{tabular}

Tab. 3b. Application of sediment quality guideline values according to CONAMA Resolution 454/2012 for the section between 100 $148 \mathrm{~cm}$. Values in $\mathrm{mg} / \mathrm{kg}$.

\begin{tabular}{cccccc} 
& \multicolumn{2}{c}{ RSG (100-148 $\mathbf{c m})$} & TEL & PEL & World Shales \\
& Min. & Max & & \\
\hline As & 4.4 & 12.2 & $<5.9$ & 37 & 13 \\
\hline $\mathbf{C r}$ & 27.1 & 90.9 & $<37.3$ & 90 & 90 \\
$\mathbf{C u}$ & 164 & 522 & $<35.7$ & 197 & 45 \\
$\mathbf{F e}$ & 55840 & 64329 & SVR & SVR & 46.7 \\
$\mathbf{M n}$ & 325 & 1200 & SVR & SVR & 850 \\
$\mathbf{N i}$ & 8.8 & 35.7 & $<18.0$ & 35.9 & 68 \\
$\mathbf{P b}$ & 19.0 & 38.5 & $<35.0$ & 91.3 & 20 \\
\hline $\mathbf{Z n}$ & 68.6 & 163.6 & $<123$ & 315 & 95
\end{tabular}


The elements $\mathrm{Fe}$ and $\mathrm{Mn}$ are kept in high concentrations throughout the core, but these elements are found naturally in high concentrations. The statistical analysis of PCoA and Pearson correlations (Fig. 4 and Table 2), indicate positive relationship between the analyzed elements and fine-grained sediments, namely clay fraction.
RESEARCH PAPER

Based on the VGQS, TEL and PEL indexes (Table $3 \mathrm{a}$ and $3 \mathrm{~b}$ ), the most affected Facies by contamination is found in the core section 154-104 cm (Facies 3), namely for As and $\mathrm{Ni}$ and a high level of contamination was found to $\mathrm{Cr}$. Concentrations of $\mathrm{Cu}$ reveal regular level of contamination to very bad through the core, with exception of Facies 1.

Tab. 4. Values of $\mathrm{D}_{\mathrm{mg}}, 1-\mathrm{D}$, density, richness, depth, and species of Testate amoebae. The sedimentary facies, were colored in order to emphasize changes in Testate amoebae community composition.

\begin{tabular}{|c|c|c|c|c|c|c|c|c|c|c|c|c|c|c|c|c|c|c|c|c|}
\hline 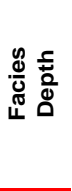 & 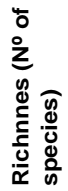 & 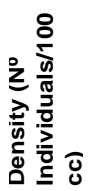 & 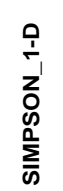 & 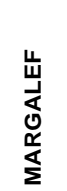 & 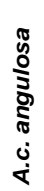 & 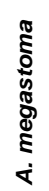 & 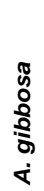 & 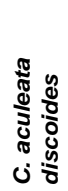 & 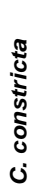 & 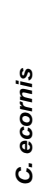 & $\begin{array}{l}\frac{\pi}{\pi} \\
\frac{\pi}{8} \\
\frac{d}{2} \\
\frac{\pi}{8} \\
0\end{array}$ & $\begin{array}{l}\frac{0}{5} \\
\frac{0}{0} \\
\frac{5}{0} \\
\frac{0}{0} \\
0 \\
0\end{array}$ & $\begin{array}{l}0 \\
0 \\
0 \\
0 \\
0 \\
0\end{array}$ & $\begin{array}{l}\frac{\pi}{2} \\
\vdots \\
0 \\
0 \\
0\end{array}$ & $\begin{array}{l}0 \\
\vdots \\
\vdots \\
0 \\
0 \\
0\end{array}$ & $\begin{array}{l}0 \\
\frac{0}{8} \\
\delta \\
\frac{0}{0} \\
0\end{array}$ & $\begin{array}{l}\frac{\pi}{5} \\
\stackrel{5}{0} \\
\vdots \\
\vdots \\
0\end{array}$ & 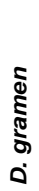 & $\begin{array}{l}\text { \& } \\
\frac{0}{3} \\
\frac{0}{0} \\
\text { ป }\end{array}$ & $z$ \\
\hline 8 & 3 & 5 & 0.0 & 0.0 & 0 & 1 & 0 & 3 & 1 & 0 & 0 & 0 & 0 & 0 & 0 & 0 & 0 & 0 & 0 & 0 \\
\hline 16 & 3 & 7 & 0.45 & 1.03 & 0 & 0 & 0 & 5 & 0 & 1 & 0 & 0 & 1 & 0 & 0 & 0 & 0 & 0 & 0 & 0 \\
\hline 18 & 2 & 3 & 0.44 & 0.91 & 0 & 0 & 0 & 2 & 0 & 0 & 0 & 0 & 1 & 0 & 0 & 0 & 0 & 0 & 0 & 0 \\
\hline 22 & 4 & 5 & 0.72 & 1.86 & 0 & 2 & 0 & 1 & 0 & 0 & 0 & 0 & 1 & 0 & 1 & 0 & 0 & 0 & 0 & 0 \\
\hline 26 & 2 & 2 & 0.50 & 1.44 & 0 & 0 & 0 & 1 & 0 & 0 & 0 & 0 & 1 & 0 & 0 & 0 & 0 & 0 & 0 & 0 \\
\hline 30 & 2 & 7 & 0.41 & 0.55 & 0 & 0 & 0 & 2 & 0 & 0 & 0 & 0 & 5 & 0 & 0 & 0 & 0 & 0 & 0 & 0 \\
\hline 34 & 3 & 3 & 0.67 & 1.82 & 0 & 1 & 0 & 1 & 0 & 0 & 0 & 0 & 0 & 0 & 0 & 0 & 0 & 0 & 0 & 0 \\
\hline 42 & 3 & 16 & 0.62 & 0.72 & 0 & 0 & 0 & 5 & 0 & 3 & 0 & 0 & 8 & 0 & 0 & 0 & 0 & 0 & 0 & 0 \\
\hline 46 & 8 & 32 & 0.80 & 2.02 & 0 & 5 & 0 & 5 & 0 & 0 & 0 & 0 & 9 & 0 & 0 & 0 & 0 & 0 & 1 & 1 \\
\hline 50 & 6 & 16 & 0.73 & 1.80 & 0 & 2 & 0 & 7 & 0 & 1 & 0 & 0 & 2 & 0 & 0 & 0 & 0 & 0 & 0 & 3 \\
\hline 54 & 6 & 4 & 0.67 & 1.67 & 0 & 3 & 0 & 1 & 0 & 0 & 0 & 0 & 1 & 0 & 0 & 0 & 1 & 0 & 0 & 0 \\
\hline 62 & 6 & 22 & 0.79 & 1.62 & 0 & 4 & 0 & 7 & 0 & 0 & 0 & 0 & 5 & 0 & 0 & 0 & 0 & 0 & 2 & 0 \\
\hline 66 & 7 & 50 & 0.70 & 1.53 & 0 & 5 & 3 & 25 & 0 & 0 & 0 & 0 & 4 & 0 & 0 & 0 & 0 & 0 & 1 & 0 \\
\hline 70 & 4 & 21 & 0.69 & 0.99 & 0 & 9 & 0 & 3 & 0 & 0 & 0 & 0 & 6 & 0 & 0 & 0 & 0 & 0 & 0 & 0 \\
\hline 74 & 4 & 19 & 0.68 & 1.02 & 0 & 0 & 0 & 8 & 0 & 0 & 0 & 0 & 6 & 1 & 0 & 0 & 0 & 4 & 0 & 0 \\
\hline 82 & 5 & 43 & 0.65 & 1.06 & 0 & 0 & 0 & 13 & 0 & 0 & 0 & 0 & 5 & 0 & 0 & 2 & 0 & 21 & 0 & 0 \\
\hline 86 & 6 & 29 & 0.72 & 1.49 & 0 & 2 & 1 & 10 & 0 & 0 & 0 & 0 & 11 & 0 & 0 & 0 & 0 & 3 & 2 & 0 \\
\hline 90 & 5 & 45 & 0.74 & 1.05 & 0 & 11 & 6 & 18 & 0 & 0 & 0 & 0 & 4 & 0 & 0 & 0 & 0 & 0 & 0 & 6 \\
\hline 94 & 6 & 32 & 0.74 & 1.44 & 0 & 0 & 6 & 12 & 0 & 0 & 1 & 0 & 9 & 0 & 0 & 0 & 0 & 0 & 0 & 0 \\
\hline 114 & 2 & 5 & 0.48 & 0.62 & 0 & 0 & 2 & 0 & 0 & 0 & 0 & 0 & 3 & 0 & 0 & 0 & 0 & 0 & 0 & 0 \\
\hline 122 & 4 & 8 & 0.72 & 1.44 & 0 & 1 & 0 & 0 & 0 & 0 & 0 & 0 & 3 & 0 & 0 & 2 & 0 & 0 & 0 & 0 \\
\hline 126 & 3 & 6 & 0.61 & 1.12 & 0 & 3 & 0 & 1 & 0 & 0 & 0 & 0 & 2 & 0 & 0 & 0 & 0 & 0 & 0 & 0 \\
\hline 132 & 3 & 3 & 0.67 & 1.82 & 0 & 1 & 1 & 1 & 0 & 0 & 0 & 0 & 0 & 0 & 0 & 0 & 0 & 0 & 0 & 0 \\
\hline 136 & 3 & 7 & 0.57 & 1.03 & 0 & 1 & 4 & 0 & 0 & 2 & 0 & 0 & 0 & 0 & 0 & 0 & 0 & 0 & 0 & 0 \\
\hline 140 & 1 & 1 & 0.00 & 0.00 & 0 & 1 & 0 & 0 & 0 & 0 & 0 & 0 & 0 & 0 & 0 & 0 & 0 & 0 & 0 & 0 \\
\hline 144 & 2 & 2 & 0.50 & 1.44 & 0 & 0 & 1 & 0 & 0 & 0 & 0 & 0 & 1 & 0 & 0 & 0 & 0 & 0 & 0 & 0 \\
\hline 148 & 4 & 7 & 0.69 & 1.54 & 1 & 0 & 3 & 0 & 0 & 0 & 0 & 0 & 2 & 0 & 0 & 0 & 0 & 0 & 0 & 0 \\
\hline 154 & 3 & 5 & 0.56 & 1.24 & 0 & 0 & 3 & 0 & 0 & 1 & 0 & 0 & 0 & 0 & 0 & 0 & 1 & 0 & 0 & 0 \\
\hline 158 & 4 & 11 & 0.71 & 1.25 & 0 & 0 & 1 & 0 & 0 & 0 & 0 & 0 & 4 & 0 & 0 & 0 & 0 & 3 & 0 & 0 \\
\hline 162 & 7 & 18 & 0.80 & 2.08 & 0 & 0 & 0 & 4 & 0 & 0 & 1 & 0 & 5 & 4 & 0 & 0 & 0 & 2 & 0 & 1 \\
\hline 167 & 3 & 10 & 0.58 & 0.87 & 0 & 0 & 5 & 0 & 0 & 0 & 0 & 0 & 0 & 4 & 0 & 0 & 0 & 1 & 0 & 0 \\
\hline 177 & 5 & 13 & 0.75 & 1.56 & 0 & 4 & 0 & 0 & 0 & 1 & 0 & 1 & 0 & 0 & 0 & 0 & 0 & 0 & 0 & 4 \\
\hline
\end{tabular}

Tab. 5. Pearson correlation between Testate amoebae. abundance and trace elements. Only the facies 3 and 4 where trace elements show the largest variations were used in the analysis. Fe and $\mathrm{Mn}$ are not shown since they are not considered pollutants by PEL and TEL Canadian indices.

\begin{tabular}{|c|c|}
\hline Elements & Specimens \\
\hline $\mathrm{Zn}$ & -0.49 \\
\hline $\mathrm{Pb}$ & -0.67 \\
\hline $\mathrm{Ni}$ & -0.56 \\
\hline $\mathrm{Cu}$ & $-0,67$ \\
\hline $\mathrm{Cr}$ & -068 \\
\hline $\mathrm{As}$ & -0.50 \\
\hline
\end{tabular}

The core has no significant contamination by $\mathrm{Zn}$ and $\mathrm{Pb}$ according to parameters of TEL and PEL. For the elements $\mathrm{Fe}, \mathrm{Mn}$ and Sc there is no reference criteria of TEL and PEL once these elements are considered naturally abundant, and Sc is not associated to anthropic activity.

Regarding the classification of species of Testate amoebae, it is important to note that the possible morphotype variations found in the RSG can be considered minimal, as no continuous variation was observed among the specimens found along the studied core. This greatly facilitated the taxonomic identification of the species, but allowed to detect significant variations of the population characteristics of Testate amoebae throughout the core (Figs. 7 and 8). 
$0-34 \mathrm{~cm}$. Core section composed by unconsolidated sediments, very fluid, and with

$34-94 \mathrm{~cm}$. The most representative facies of the core. It is composed by more consolidated sediments. It is possible to observe a plan-parallel stratification with intercalations, at centimetric level, of mud pattern color of black and brown.

94-154 cm. Gradual transition to facies more consolidated and more homogeneously with a clearer brown color, it is possible to see a subtle plan-parallel stratification.

$154-177 \mathrm{~cm}$. Erosion unconformity marking the contact between the facies of mud-clay grey color to facies with a clearer color gradation in direction to the base of the core, with high concentration of roots that

decrease towards the base, suggestive of soil.

$177-235 \mathrm{~cm}$. Gradual transition to clay levels well consolidated with light grey color with variegated texture formed by spots of ocher color followed by a mottled aspect.

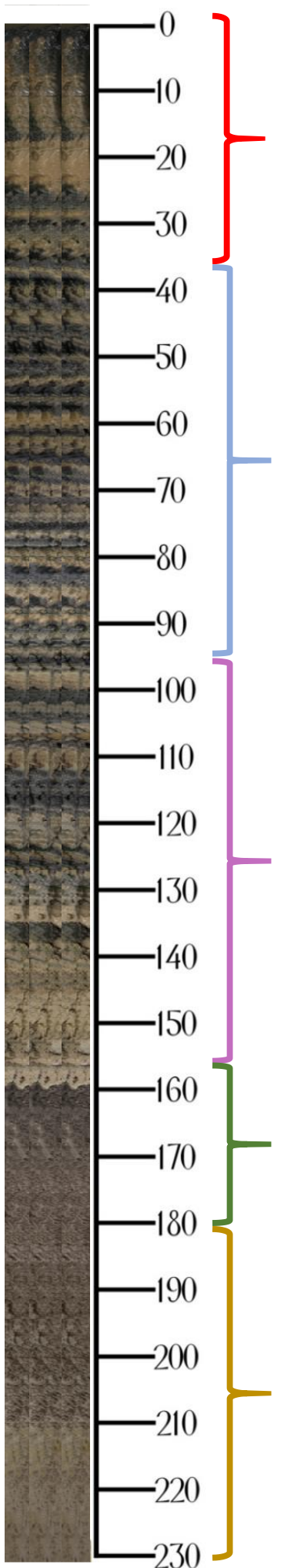

\section{0-34 cm FACIES V}

Sharp decline in abundance and richness of populations of Testate amoebae. Predominance of $C$. aculeata discoide followed by $D$. corona

\section{4-94 cm FACIES IV}

Layer presenting the highest abundance and richness of Testate amoebae. Predominance of $C$. aculeata discoide followed by $D$. corona, A. megastoma, D. gramen, D. oviformis, N. tuberculata, L. globulosa, Protocurcubitella coroniformis.

\section{4- $154 \mathrm{~cm}$ FACIES III}

Fall of abundance and richness of Testate amoebae. Predominance of $D$. corona followed by Arcella gibbosa and A. megastoma, D. gibbosa. Presence of Netrelia wailesi.

\section{4-177cm.FACIES II}

Emergence of Testate amoebae populations presenting equity in richness among the predominant Taxa. Arcella gibbosa, A. megastoma, C. aculeata discoide.

\section{$177-235 \mathrm{~cm}$ FACIES I}

Facies.

Testate amoebae Pre-reservoir absence from RSG and description of its facies.

Fig. 6. Facies of the sedimentary core of the Salto Grande reservoir. 

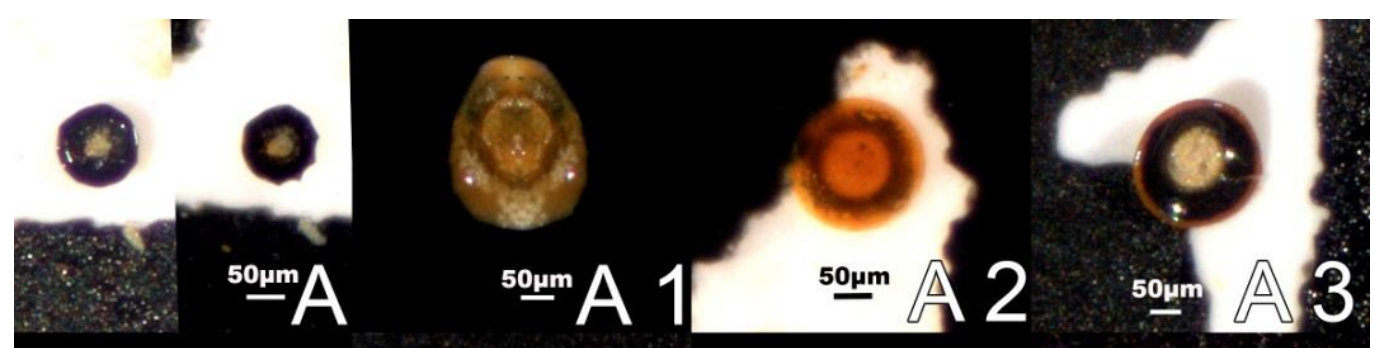

RESEARCH PAPER
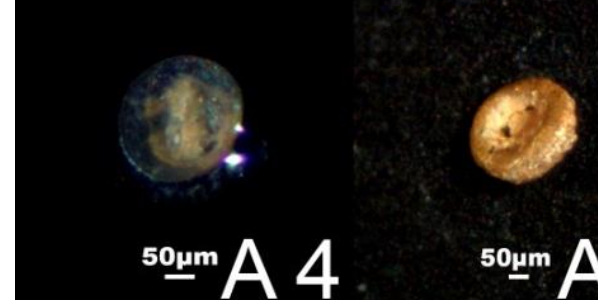

(2)

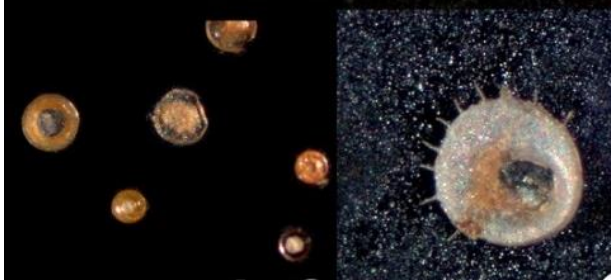

A 8
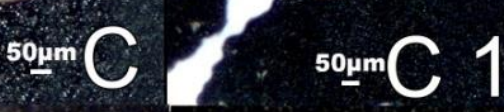

50pm $\bigcirc$
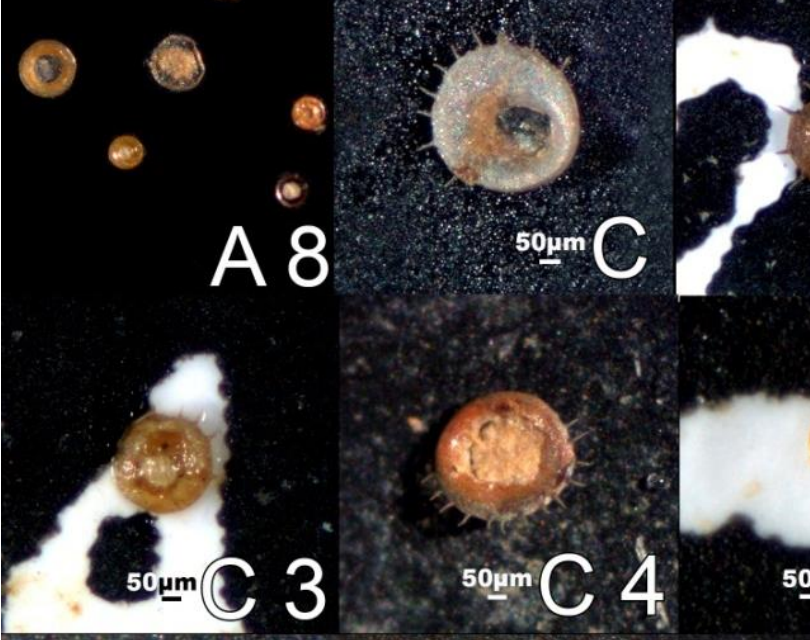

opm $\mathrm{A}$

${ }_{\text {50pm }} \boldsymbol{A} \quad 7$
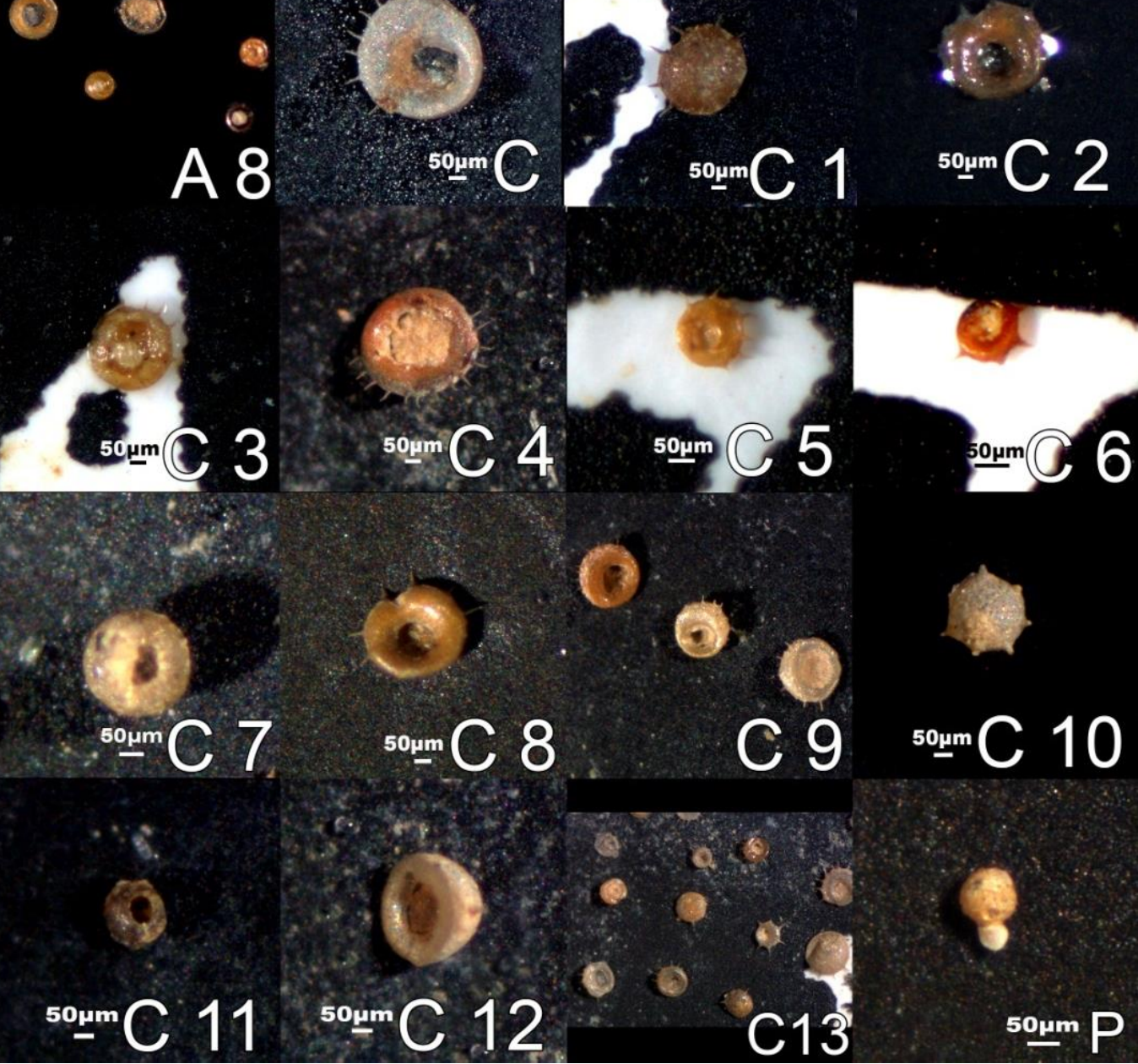

50pm 10

Fig. 7. Taxa of tecamebas found in the sediments of the RSG. A - Arcella costata angulosa (Playfair, 1918); 109 $\mu \mathrm{m}$. A1-A4 Arcella megastoma (Pénard, 1913); A1 - $262 \mu \mathrm{m}, \mathrm{A} 2$ - $208 \mu \mathrm{m}, \mathrm{A} 3$ - $219 \mu \mathrm{m}$ and; A3 - $207 \mu \mathrm{m}$, respectively. A5, A6 - Arcella gibbosa (Pénard,1890); $264 \mu \mathrm{m}$, $168 \mu \mathrm{m}$ respectively. A7-Arcella specimens in reproductive phase. A8 - Arcella specimens with different size and morphotypes. C to C9 - Centropyxis aculeata discoide (Ehrenberg, 1859); C - $347 \mu \mathrm{m}, \mathrm{C} 1-309 \mu \mathrm{m}, \mathrm{C} 2-317 \mu \mathrm{m}, \mathrm{C} 3-259 \mu \mathrm{m}, \mathrm{C} 4-365 \mu \mathrm{m}, \mathrm{C} 5$ - $130 \mu \mathrm{m}, \mathrm{C} 6-$ $91 \mu \mathrm{m}, \mathrm{C} 7-221 \mu \mathrm{m}, \mathrm{C} 8-302 \mu \mathrm{m}, \mathrm{C} 10-210 \mu \mathrm{m}$, C11 - $188 \mu \mathrm{m}$ and C12 - $269 \mu \mathrm{m}$. Centropyxis ecornis (Ehrenberg, 1841). C13 - Centropyxis; specimens with different size and species morphotypes. P- Pontigula sp. (Rhumbler, 1896); $106 \mu \mathrm{m}$. 


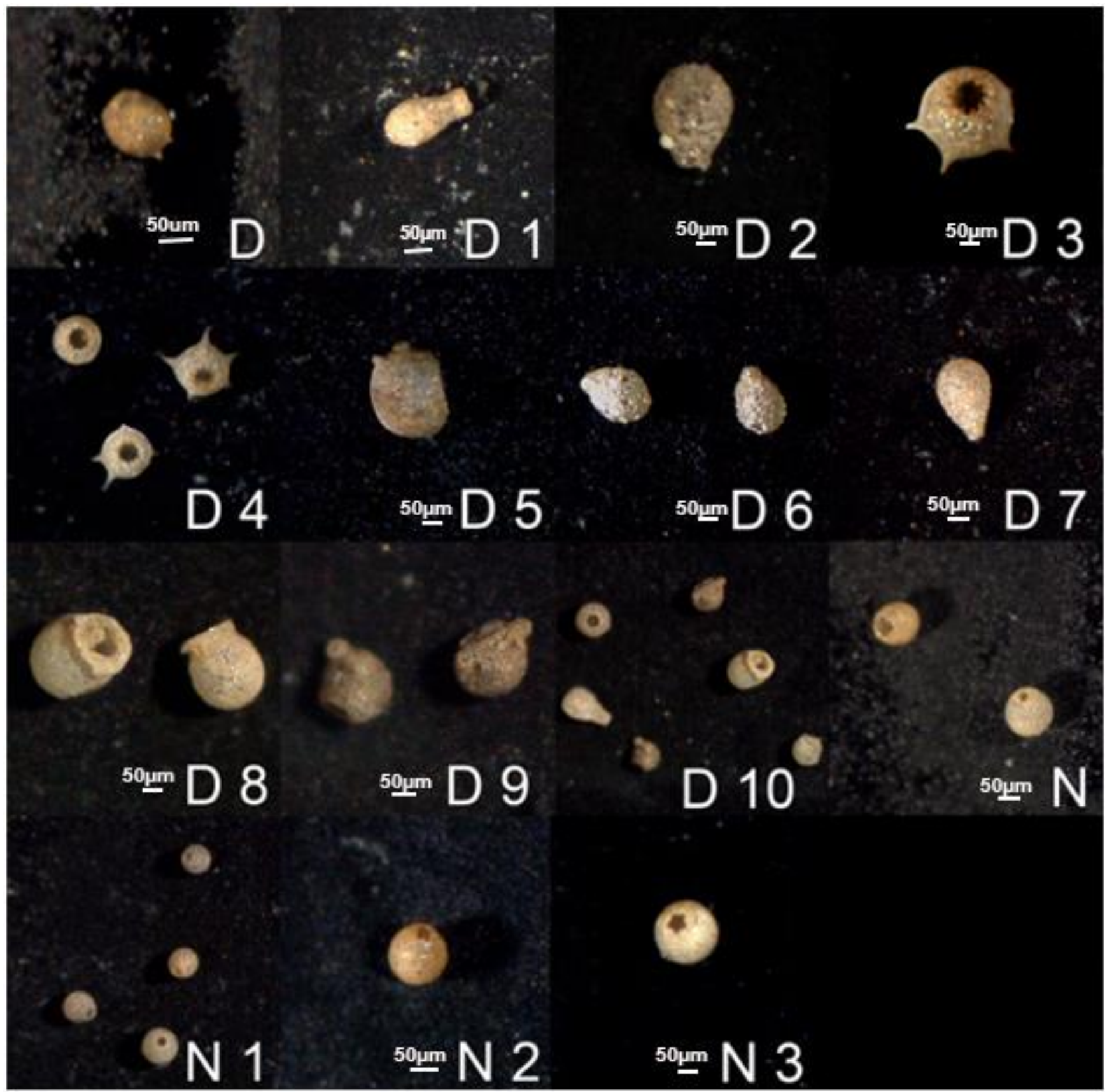

Fig. 8. D - Difflugia chaquensi (Vucetich, 1989); $100 \mu \mathrm{m}$. D1 Difflugia capreolata (Pénard 1902); $243 \mu \mathrm{m}$. D2 - Difflugia oblonga (Ehrenberg,

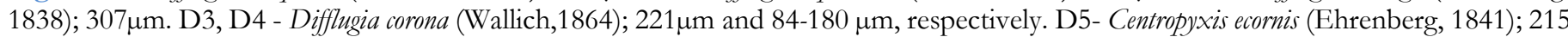

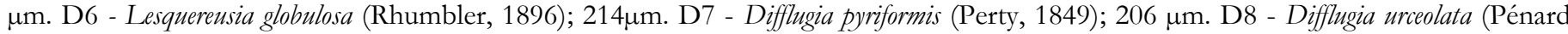
1902); $212 \mu \mathrm{m}$. D9 - Difflugia oblonga capreolata (Ehrenberg, 1838); $119 \mu \mathrm{m}$. D10 - Difflugia spp. N, N1- Netzelia oviformis (Cash, 1909); $100 \mu \mathrm{m}$. N2, N3 - Netzelia wailesi (Ogden, 1980); $140 \mu \mathrm{m}$ and $112 \mu \mathrm{m}$, respectively. 


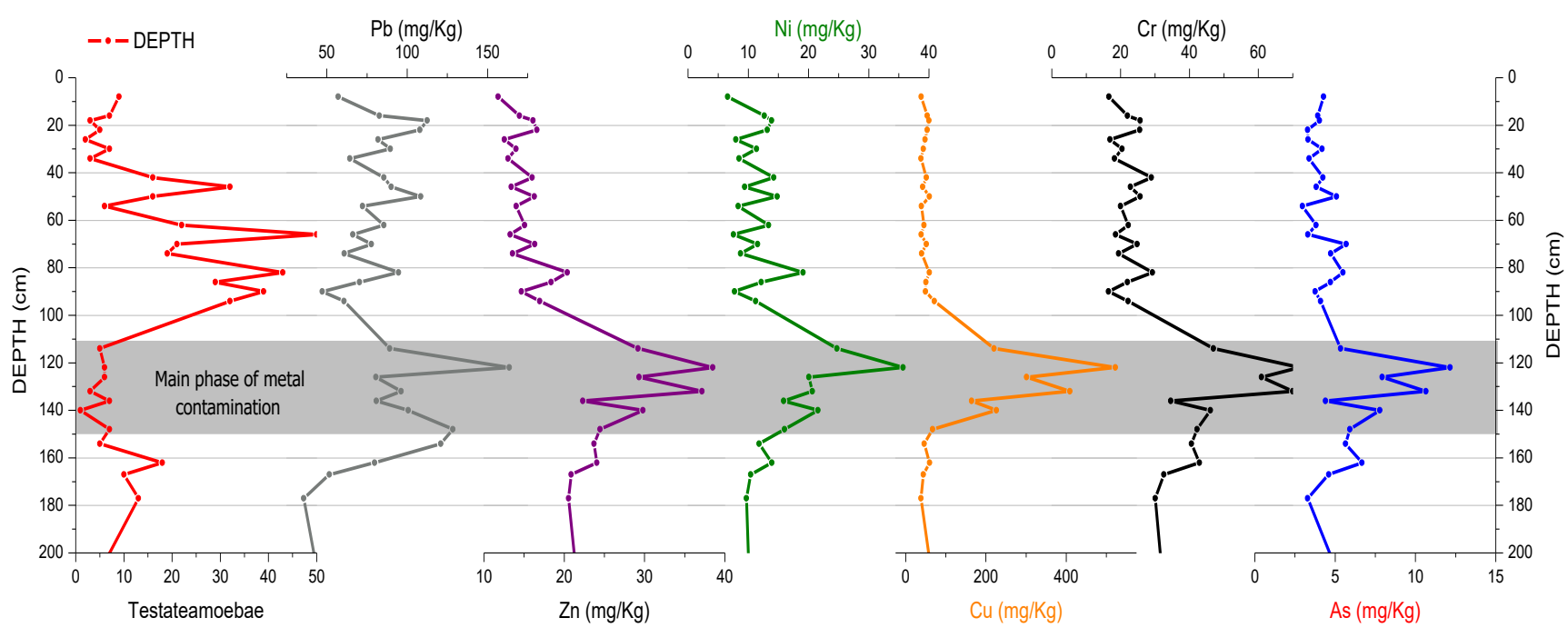

Fig. 9. Testate amoebae number of specimens plotted in the right axis, and most important trace elements pollutants plotted in left axis. The number of specimens is in red, $\mathrm{Cu}$ in yellow, $\mathrm{Zn}$ in deep blue, $\mathrm{Cr}$ in black, $\mathrm{Pb}$ in brown, $\mathrm{Ni}$ in green, and As in blue. $\mathrm{X}$ axis shows depth.

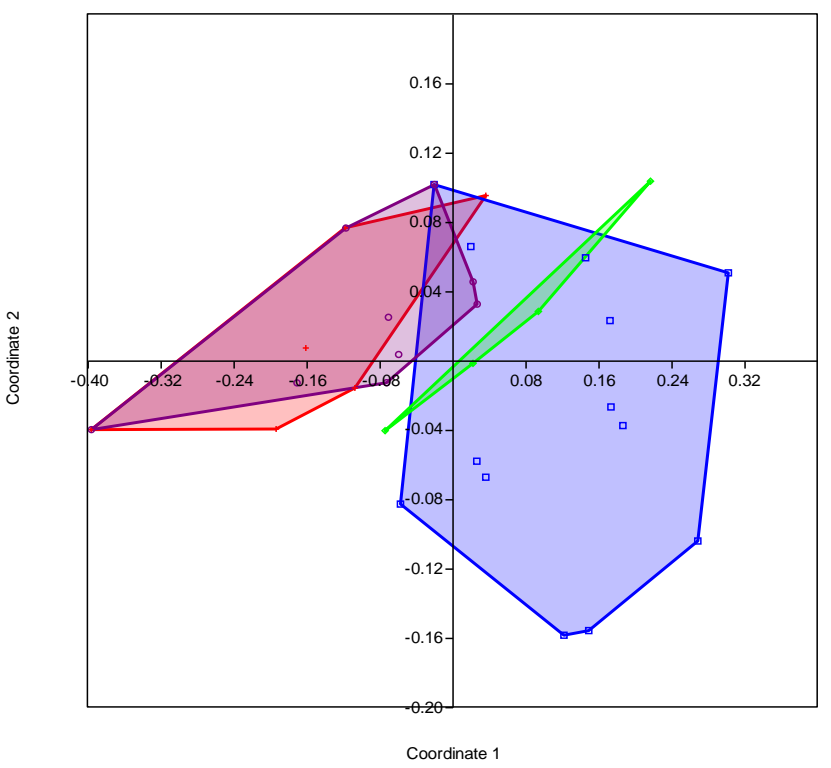

Fig. 10. NMDS Plot (Gower) diversity indices, as well as specimens and Taxa number, in function of depth. The two purple and red polygons located between the -0.4 and +2 points of coordinate 2 and -0.04 and +0.10 of coordinate 1 show the similarity of the two events of decline of abundance, richness and diversity of populations of Testate amoebae. The interpolating blue and green polygons between the points -0.04 and +0.29 of coordinate 2 and -0.16 to +0.10 of coordinate 1 show the two events that display abundance, wealth and diversity in the populations of Testate amoebae.

From the variations of the Testate amoebae populations, combined with the results of the abiotic data (nutrient contents, trace elements), it was possible to identify sedimentary facies, representative of important moments in the environmental history of the RSG (Figs. 6 and 9).

These events were demonstrated through the statistical analysis NMMDS (Fig. 10) in which it was possible to observe two clusters with overlapping areas; a grouping that marks the intersection of Facies 3 and 5 that presented the events that showed a significant decrease in richness and abundance of the populations of Testate amoebae and a second group that overlaps the Facies 2 and 4 that marked the events of high richness and abundance of the Testate amoebae.

The predominant genera found in the RSG is shown in Figure 6 and Table 4, are Centropyxis, Difflugia and Arcella, genera that are considered opportunistic and tolerant to contaminated environments (Patterson and Kumar 2000; Farrooqui et al., 2012; Qin et al., 2013). Among these three genera, Arcella was shown to be the most tolerant and opportunistic, followed by Difflugia in RGS. Centropyxis aculeata discoide should be the most sensitive species to contamination by metals since its abundance deeply decline declines as trace metals concentrations increase. The same behavior was also observed by Farooqui et al. (2012). The other RSG taxa were considered rare because they were represented by few individuals.

To assess the influence of anthropic activities, the use of bioindicators for the biomonitoring of water systems is less expensive than the use of physico-chemical indicators that require time and cost for purification, qualification and quantification. 


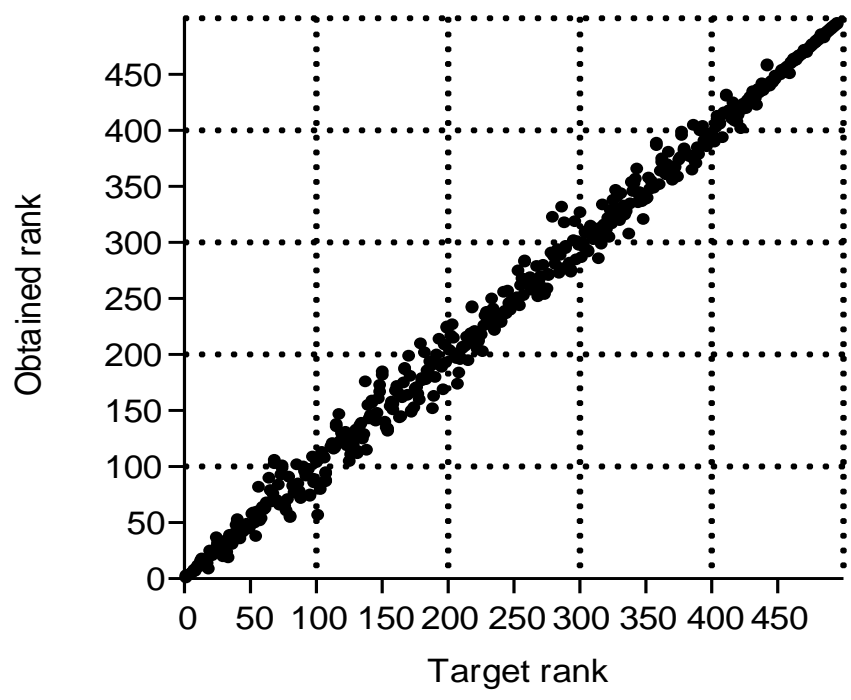

Fig. 11. Sheppard plot indicating the quality of results of the NMMDS graphic, almost all points are aligned in a single straight line.

The advantage that these thecamoebians organisms offer is to have quick responses to the introduction of pollutants, because they have a short life cycle, practically sampling in real time what happens in the environment, and being able to keep this information in the fossil record. They can indicate environmental changes such as climate, sea level oscillations, introduction of pollutants into the environment (Markert et al., 2003).

\section{Conclusion}

The beginning of the RSG dam filing was marked by a change in sediments grain size, which became quite fine. The sediment core witnessed the input of trace elements to the reservoir, as well as changes in populations of Testate amoebae. It is possible to infer that the rise of clay fraction in sediments played an important role in trace elements adsorption during 65 years, from the filling of the RSG until 2015.

Changes of Testate amoebae populations were conditioned by the input of trace elements. The results of this worl evidence that these organisms are good bioindicators of pollution by metals. The most tolerant species to metals enrichment were Arcella megastoma and Difflugia corona. The most sensitive species were Difflugia gramen, Lesquereusia globulosa and Netzelia tuberculata.

It is observed that Testate amoebae communities are excellent bioindicators of pollutants in lake sediments and multiproxies analysis are required to better infer the ecosystem response to complex interaction between abiotic and biotic parameters.
Acknowledgment

We thank the Americana Barco Escola in the person of Mr. Jõao Carlos Pinto, for the logistic support in collecting the core and Miss Patricia J. Viana for collaboration in fieldwork.

\section{References}

Adl, S.M., Simpson, A.G.B., Farmer, M.A., Andersen, R.A., Anderson, O.R., Barta, J.R., Bowser, S.S., Brugerolle, G., Fensome, R.A., Fredericq, S., James, T.Y., Karpov, S., Kugrens, P., Krug, J., Lane, C.E., Lewis, L.A., Lodge, J., Lynn, D.H., Mann, D.G., Mccourt, R.M., Mendoza, L., Moestrup, Ø., Mozley-Standridge, S.E., Nerad, T.A., Shearer, C.A., Smirnov, A.V., Spiegel, F.W., Taylor, M.F.J.R., 2005. The New Higher Level Classification of Eukaryotes with Emphasis on the Taxonomy of Protists. Journal of Eukaryotic Microbiology 52, 399-451. http://dx.doi.org/10.1111/j.1550-7408.2005.00053.x

Alves, G.M., Lansac-Tôha, F.A., Velho, L.F.M., Joko, C.Y, Costa, D.M., 2007. New records of testate lobose amoebae (Protozoa, Arcellinida) for the Upper Paraná River floodplain. Acta Limnologica Brasiliensia 19(2), 175-195pp.

Asioli, A., Medioli F., Patterson, R.T., 1996. Thecamoebians as tool for reconstruction of paleoenvironments in some Italian lakes in the foothills of southern Alpes (Orta, Varese, Candia). Journal of Foraminiferal Research 26(3), 248-265.

Booth, R.K., 2001. Ecology of Testate amoebae (Protozoa) in two lake superior coastal wetlands: implications for paleoecology and environmental monitoring. Wetlands 21, (4), 564-576. https://doi.org/10.1672/0277-5212(2001)021[0564:EOTAPI]2.0.CO,2

CCME-Canadian Environmental Quality Guidelines - Summary Tables http://www.ec.c.ca/ceggrcqe/English/ ceqg/sediment/default.cfm

Chau, Y.K., Shiomi, M.T., 1972. Complexing properties of nitrilotriacetic acid in the lake environment. Water, Air, and Soil Pollution 1, 149-164. https://doi.org/10.1007/BF00187704

CONAMA (Conselho Nacional do Meio Ambiente), 2012. Resolução no 454, de 1 de novembro de 2012. Estabelece as diretrizes gerais e procedimentos referenciais para o gerenciamento do material a ser dragado em águas sob jurisdição nacional. http:/ / www.mma.gov.br/

Cruz, C.F. 2004. Foraminíferos e tecamebas (arcellans) recentes na baía de iguape e baixo curso do Rio Pàraguaçu: ocorrência e distribuição. MsD Thesis, Universidade Federal da Bahia.

Decloître, L., 1953. Recherches sur les Rhizopodes Thécamoebiens d'A.O.F. Mémoires de l'Institut Français d'Afrique Noire, 31, 1-249 pp.

Dias-Brito, D., Moura, J.A., Würdig, N., 1988. Relationships between Ecological models based on ostracodes and foraminifers from Sepetiba Bay (Rio de Janeiro, Brazil). In: Hanay, T., Ikeya, N., Ishizaki, K. (eds.), Evolutionary Biology of Ostracoda, Elsevier, pp. 467-484.

Duleba, W., Coimbra, J.C.S., Petri, S., Barbosa, C.F., 2005. Foraminíferos, tecamebas e ostracodes recentes utilizados como bioindicadores em estudos ambientais brasileiros. In: 
Souza, C.R.G., Suguio, K., Oliveira, A.M.S., de Oliveira, P.E. (eds.), Quaternário do Brasil, Holos Editora (9), 176-210.

Duleba, W., Debenay, J.P., Melo e Sousa, S.H. 2004. Caracterização ambiental dos Estuários dos Rios Guaraú e Una, a partir de análises sedimentológicas e das associações de foraminíferos e tecamebas. Estação Ecológica Juréia- Itatins. Ambiente Físico, Flora e Fauna/ Editora Holos. ISBN 8586699373

Duleba, W., Debenay, J.P., Eichler, B.B., 1999a. Foraminíferos e tecamebas como bioindicadores da circulação heterodinâmica do estuário do Rio Verde e do Lago Itacolomy, Estação Ecológica Jureia Itatins, Brasil. In: Congresso da Associação Brasileira do Quaternário, ABEQUA, Porto Seguro.

Eichler, B.B., Bonetti, C., 1995. Distribuição de foraminíferos e tecamebas ocorrentes no Manguezal Dorio Baguaçu, Cananéia, São Paulo, relação com parâmetros ambientais. Pesquisas em Geociências 22 (1-2), 32-37.

Espíndola, E.L.G., Leite M.A., Dornfeld, C.B. 2004. Reservatório de Salto Grande (Americana, SP): Caracterização, Impactos e Propostas de Manejo. Editora RIMA São Carlos, 484 p.

Esteves, F.A. 2011. Fundamentos da Limnologia. $3^{\circ}$ Ed. Editora Interciência. ISBN 978-85-7193-323-337

Farooqui, A., Kumar, A., Swindles, G.T., 2012. Thecamoebians communities as proxies of seasonality in Lake Sadatal in the Ganga-Yamuna Plains of North India. Paleontological Electronica PE, Article Number 15.1.3A, 19 p.

Ferreira, F., Leiptniz, I.I, Leão, C.J., Hansen, M.A.F., 2006. Tecamebas em sedimentos do Rio Tramandaí e da Lagoa do Passo, planície costeira norte do Estado do Rio Grande do Sul, Brasil. Gaea, Journal of Geoscience 2(2), 66-74.

Finlay, B.J., Corliss, J.O., Esteban, G., Fenchel, T., 1996. Biodiversity at the microbial level: the number of free living ciliates in the biosphere. The Quarterly Review of Biology 71, 221-237.

Folk, R.L., Ward, W.C., 1957. Brazos River bar: a study in the significance of grain size parameters. Journal of Sedimentary Petrology 27, 3-26.

Fonseca, M.F., Matias, L.F., 2014. Análise do uso da Terra e do componente Clinográfico por meio de geoprocessamento: o entorno do reservatório de Salto Grande-SP. Boletim de. Geografia, Maringá, 32 (3), 48-60.

Gomes e Souza, M.B., 2008. Guia das Tecamebas, Bacia do Rio Peruaçu- Minas Gerais. Subsídio para conservação e monitoramento da Bacia do Rio São Francisco. Editora UFMG. Belo Horizonte, MG. ISBN 978-85-7041-649-0

Guilherme, L.R.G., Marques, J.J., Pierangeli, M.A.P., Zuliani, M.Q., Campos, M.L., Marchi, G., 2005. Elementos-traço em solos e sistemas aquáticos. In: Tópicos em ciências do solo. Viçosa, MG: Sociedad Brasileira de Ciência do Solo 4, 345-390.

Hammer, O., Harper, D.A.T., Ryan, P.D., 2001. PAST: Paleontological Statistic software package for education and data Analysis. Paleontologia Eletrônica 4 (1), 1-9.

IBGE, Censo Demográfico 2010. Malha Municipal Digital do Brasil. http://www.ibge.com.br/cidades@, accessed December 2014
Jenne, E.A., 1968. Trace Inorganic in Water. Advances in Chemistry 73, 337-387. http://dx.doi.org/10.1021/ba-19680073

Lahr, D.J.G., 2006. Taxonomia dos Arcellenidea Kent, 1880(Protista: Ramicristates) do Parque Ecológico do Rio Tietê. MsD Thesis, Universidade de São Paulo, Brazil.

Lansac-Tôha, F.A., Velho, L.F.M., Bonecker, C.C., 1999. Estrutura da comunidade zooplanctônica antes e após a formação do reservatório de Corumbá-GO. In Henry, R. (ed.), Ecologia de reservatórios: estrutura, função e aspectos sociais Fapesp/Fundibio, Botucatu, p. 347-374.

Leite, M.A., 2002. Análises do aporte da taxa de sedimentação e da concentração de metais na água, plâncton e sedimentos do Reservatório de Salto Grande Americana-SP. PhD Thesis, Universidade de São Paulo, Brazil, 199 p.

Lockwood, R.A., Chen, K.Y., 1973. Adsorption of Mercury (II) by Hydrous Manganes e Oxides. Enviromental. Science \& Technology. 7 (11), 1028-1034. http://dx.doi.org/10.1021/es60083a006

Magurran, A.E., 2004. Measuring Biological Diversity. Oxford Blackwell Science Ltda, 256 p.

Markert, B.A., Breure, A.M., Zechmeister, H.G., 2003. Bioindicators and Biomonitors: Principles, Concepts, and Applications. Elsevier Amsterdam. ISBN: 9780080527970

Medioli, F.S., Scott, D.B., 1983. Holocene Arcellacea (Thecamoebians) from Eastern Canada. Cushman Foundation Special Publication 21, 5-63.

Medioli, F.S., Scott, D.B., 1988. Lacustrine thecamoebians (mainly Arcellaceans) as potential for paleolimnological interpretations. Palaeogeography, Palaeoclimatology. Palaeoecology, 62, 361 386. http://dx.doi.org/ 10.1016/0031-0182(88)900-62-4.

Meyer, C., Gilbert, D., Gillet, F., Moskura, M., Franchi, M., Bernard, N., 2012. Using "bryophytes and their associated Testate amoebae" microsystems as indicators of atmospheric pollution. Ecological Indicators 13, 144-151. http://dx.doi.org/10.1016/jcecolind.2011.05. .020.

Mignot, J.-P., Raikov, I. B. 1992. Evidence for meiosis in the testate amoeba Arcella. The Journal of Eurkaryotic Microbiology 39, 287-289. http://dx.doi.org/10.1111/j.1550-7408.1992.tb01316.x

Nguyen-Viet, H., Bernard, N., Mitchell, E.A.D., Badot, P.M., Gilbert, D., 2008. Effect of lead pollution on Testate amoebae communities living in Sphagnum fallax: An experimental study. Ecotoxicology and Environmental Safety 69, 130-138, Doi.org/10.1016/j.ecoenv. 2007.02.007.

Ogden, C.G., Hedley, R.H. 1980. An atlas of freshwater testate amoeba. British Museum (Natural History) and Oxford University Press, Oxford.

Oliveira, D., 1999. Análises ambiental dos canais da Bacia Hidrográfica do Rio Itanhaém-SP Brasil, com base em tecamebas e foraminíferos. Rio Claro. MsD Thesis, Universidade Estadual Paulista, Brazil.

Onianwa, P.C., 2001. Monitoring atmospheric metal pollution: areviews of the use of mosses as indicators? Environmental Monitoringand Assessment 71 (1), 13-50. https://doi.org/10.1023/A:1011660727479 
Patterson, R.T., Kumar, A., 2000a. Assessment of Arcellacea (Thecamoebian) assemblages, species, and strains as contaminant indicators in James Lake, Northeastern Ontario, Canada. Journal of Foraminiferal Research, 30(4), 310-320. https://doi.org/10.2113/0300310

Patterson, R.T., Kumar, A., 2000b. Use of Arcellacea to gauge levels of pollution and remediation of industrially polluted lakes. In Martin, R. (ed.), Environmental Micropaleontology, The Application of Microfossils to Environmental Geology, pp. 257-278. ISBN-0-306-46232-x

Patterson, R.T., Barker, T., Burbidge, S.M., 1996. Arcellaceans (thecamoebians) as proxies of arsenic and mercury contamination in northeastern Ontario lakes. Journal of Foraminiferal Research 26, 172-183. https://doi.org/10.2113/gsjfr.26.2.172

Pchelin, I.M., 2010/2011. Testate amoeba Arcella vulgaris (Amoebozoa, Arcellidae) is able to survive without the shell and construct a new one. Protistology 6 (4), 251-257.

Pénard, E. 1902. Faune rhizopodique du basin du Léman. Henry Kündig, Genève. pp. 1-714

Porter, S.M., Meisterfeld, R., KnollL, A.H. 2003. Vase-Shaped Microfossil from the Neoproterozoic Chuar Group, Grand Canyon. A classification guided by modern Testate Amoeba. Journal of Paleontology 77(3), 409-429. https://doi.org/10.1666/0022-3360(2003)077<0409:VMFTNC>20.CO,2

Qin, Y., Fournier, B., Lara, E., Gu, Y., Wang, H., Cui, Y., Zhang, X., Mitchell, E.A.D, 2013. Relationships between testateamoeba communities and water quality in Lake Donghu, a large alkaline lake in Wuhan, China. Frontiers of Earth Science 7 (2), 182-190. https://doi.org/10.1007/s11707-013-0352-4

Raikov I.B., Karadzhan B.P., Kaur R., Mignot, J.P. 1989. Nuclear fine structure at interphase and during encystment in two forms of the testacean Arcella vulgaris. Europ. J. Protistol. 24, 369380pp. https://doi.org/10.1016/S0932-4739(89)80007-0
Skoog D.A., West, D.M., Holler, F.J., 1998. Fundamentals of Analytical Chemistry. Saunders College Publishing, 7 ed., 577p.

Silveiro, P.F. 2003. Bases técnico-científicas para a derivação de valores-guias de qualidade de sedimentos para metais: experimento de campo e de laboratório. São Carlos, Doctorate Thesis, Universidade de São Carlos, SP. Brazil.

Török, J. K. 2001. Fine Structure and Biometric Characterization of the Shell in the Rare Testacean Species Hyalosphenia punctata Penard (Protozoa: Testacealobosia) Acta Protozoologica 40, 291-296.

USEPA (United States Environmental Protection Agency) 1996. Method 3050B. Acid Digestion of Sediments, Sludge and soil. Revision 2.

USEPA (United States Environmental Protection Agency) 2000. Health Assessment Document for Diesel Engine Exhaust, EPA/600/8-9. /057F/, National Center for Environmental Assessment Washington, DC.

Vucetich, M.C.,1989. Descripción y ultraestructura tecal de dos espécies nuevas del género Difflugia Leclerc. Limnobios, La Plata, 2 (10), 740-743.

Xu, M., Cao, H., Xie, P., Deng. D., Feng, W., Xu, J., 2005. Use of PFU protozoan community structural and functional characteristics in assessment of water quality in a large, highly polluted freshwater lake in China. Journal of Environmental Monitoring. 7, (7), 670-674, https://doi.org/10.1039/B504396B

Yudina, T. A., Sukhanova, K. M. 2000. Cell biology and life cycle of the testateamoeba Corythion delamarei. Cytology 42, 613-623.

Zitko, V., Carson, W.V., 1972. Release of heavy metals from sediments by nitrilotriaceticacid (NTA). Chemosphere 3, 113118. https://doi.org/10.1016/0045-6535(72)90047-1. 